\title{
Desarrollo de Cara y Cuello en Vertebrados
}

\author{
Face and Neck Development in Vertebrates
}

"Manuel Meruane; *,** Carolina Smok \& ${ }^{* * *}$ Mariana Rojas

MERUANE, M.; SMOK, C. \& ROJAS, M. Desarrollo de cara y cuello en vertebrados. Int. J. Morphol., 30(4):1373-1388, 2012.

RESUMEN: El desarrollo embrionario de las regiones facial, del cuello, cavidades nasales y oral en conjunto con las glándulas asociadas, involucra el crecimiento y fusión tridimensional de múltiples procesos. Existe participación de elementos derivados de las 3 capas embrionarias locales y adicionalmente de células derivas de la cresta neural, procedentes de los rombómeros vecinos. Estas últimas se ven involucradas en la formación del esqueleto local, entre otras estructuras. El estudio evolutivo desde los vertebrados sin mandíbula nos enseña como se expresan los genes Hox en las diferentes especies, y como esto determina la formación de diferentes estructuras. En la siguiente revisión contemplamos algunos aspectos morfológicos, moleculares y evolutivos básicos del desarrollo facial y cervical, con énfasis en mamíferos con un epílogo referente a las malformaciones de la región en humanos.

PALABRAS CLAVES: Cara; Cuello; Arcos faríngeos; Crestas neurales; Malformaciones.

Desarrollo inicial de la región cefálica y del cuello. La región craneal de los vertebrados consta de 3 elementos principales que fusionados forman una estructura armoniosa. El elemento más antiguo en la filogenia es el viscerocráneo o esplacnocráneo identificado desde los protocordados, se compone de una serie de arcos branquiales o faríngeos asociados a las regiónes oral y faríngea; está compuesto de ectomesénquima derivado de la cresta neural. El condrocráneo o neurocráneo rodea y da soporte al encéfalo en conjunto con los principales órganos de los sentidos, está compuesto por cartílago o hueso endocondral. El tercer elemento es el dermatocráneo que constituye el "envoltorio" externo del cráneo en la mayor parte de los vertebrados, se compone de huesos dérmicos.

El estomodeo o cavidad oral primitiva en conjunto con la faringe embrionaria, que corresponde a la región cefálica del intestino anterior, se relacionan con el desarrollo del esplacnocráneo. Durante las etapas iniciales del desarrollo de los cordados las paredes de la faringe desarrollan hendiduras, que en muchos cordados primitivos constituyen aberturas a través de las cuales se podían alimentar mediante un flujo unidireccional de agua, que entra por la cavidad oral y sale a través de éstas. En peces y anfibios estas hendiduras se asociaron a branquias (Fig. 1), en la cuales existe un flujo sanguíneo a través de capilares que permiten el intercambio respiratorio. En los vertebrados terrestres estas hendiduras no se abren y por lo tanto no constitu- yen ningún derivado del adulto, sino que formarán la región del cuello.

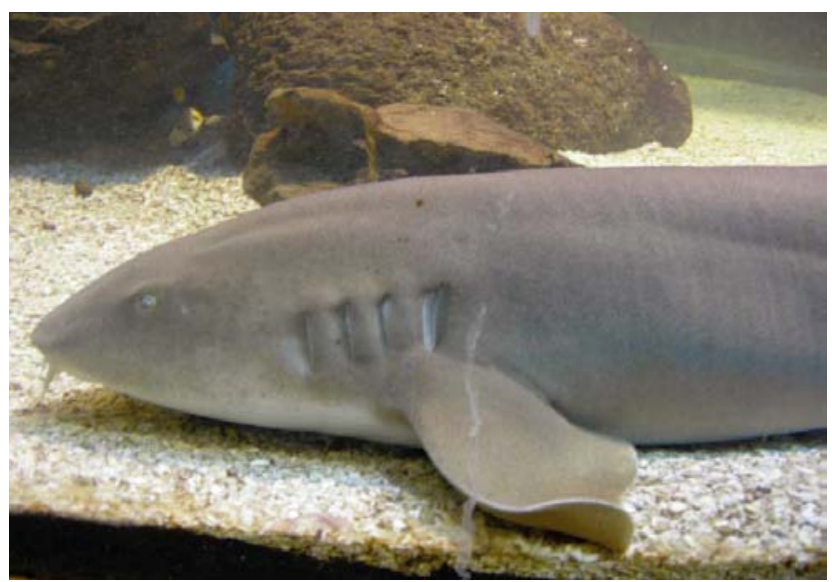

Fig. 1. Tiburón, se observa la presencia de 4 hendiduras branquiales.

Los elementos esqueléticos de los arcos faríngeos son derivados exclusivamente del ectomesénquima procedente de las crestas neurales, no del mesodermo. Las células de la cresta neural al dejar su localización inicial, próxima al tubo neural, contribuyen en la formación del mesénquima que se diferenciará en células nerviosas craneales, hueso y cartílago entre otras estructuras. Sólo los vertebrados poseen estas células, sin embargo su origen es incierto. Al parecer evolucionaron desde células en los límites de la placa neural/epi-

* Laboratorio de Embriología Comparada, Programa de Anatomía y Biología del Desarrollo, ICBM. Facultad de Medicina, Universidad de Chile.

** Universidad Autónoma de Chile, Santiago, Chile.

**** Programa de Doctorado en Ciencias Morfológicas, Universidad de La Frontera, Temuco, Chile. 
dermis desde un protocordado ancestral, ya que éstos expresan en su línea mediana dorsal ectodérmica muchos de los mismos genes expresados en las células de la cresta neural de los vertebrados, tales como BMP2, Pax3, Pax7, Msx, Dll y Snail. Sin embargo, las células de los protocordados que expresan estos genes no migran ni se diferencian hacia un amplio rango de tejidos (Gilbert, 2005).

El cerebro posterior está segmentado en rombómeros y cada uno de estos segmentos aporta células de la cresta neural que van a poblar determinados arcos faríngeos, dando lugar a diferentes estructuras craneales. Las células de los rombómeros 1 y 2 migran al interior del primer arco faríngeo para producir huesos faciales, el cartílago del primer arco y en mamíferos el incus y el malleus. Las células del rombómero 4 invaden el segundo arco faríngeo para dar lugar al estapedio, proceso estiloides y parte del hioides. El rombómero 6 libera células a los arcos faríngeos 3 y 4 que formarán los cartílagos hioides y tiroides. Las células de los rombómeros 3 y 5 no migran (Fig. 2).

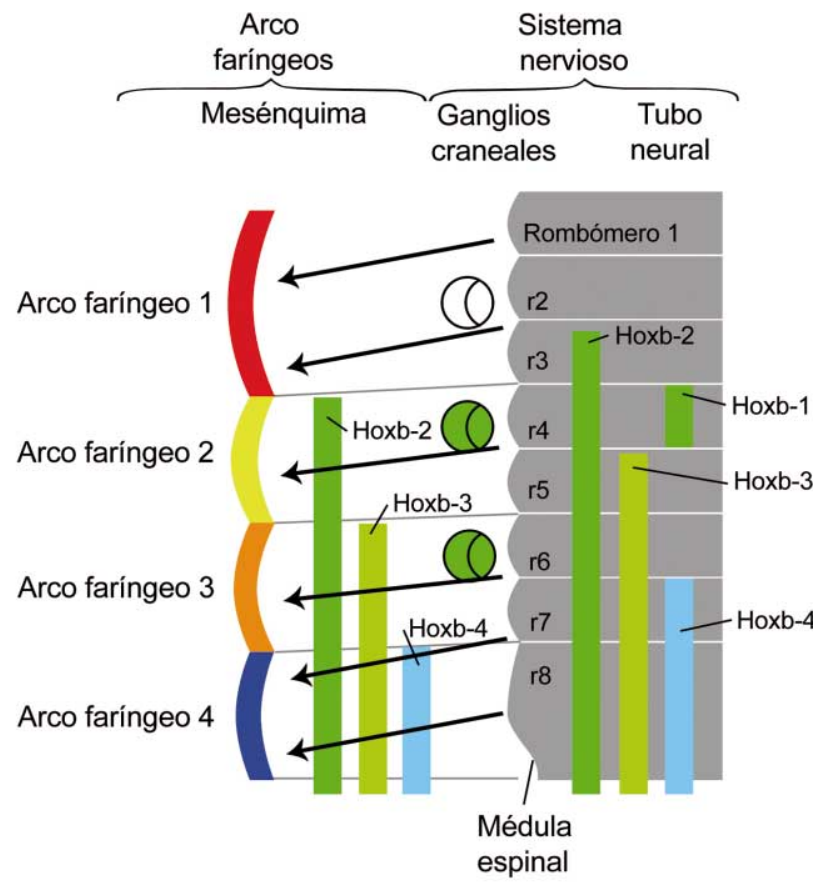

Fig. 2. Migración de las células de la cresta neural desde los rombómeros a sus respectivos arcos, y los genes Hox implicados.

Los vertebrados más primitivos como los mixinoideos (mixina) y los pretomizóntidos (lampreas) son agnatos (Fig. 3), es decir no poseen mandíbula. La lamprea particularmente ha servido para el estudio de la evolución de la mandíbula. Según los antecedentes aportados por este vertebrado actual, así como de otros fósiles, no existe un ancestro con arcos faríngeos idénticos e indiferenciados. Lo que se ha visto es que el primer y segundo arco siempre se ha asociado a alguna estructura que permitiría la alimentación (Kuratani, 2004).

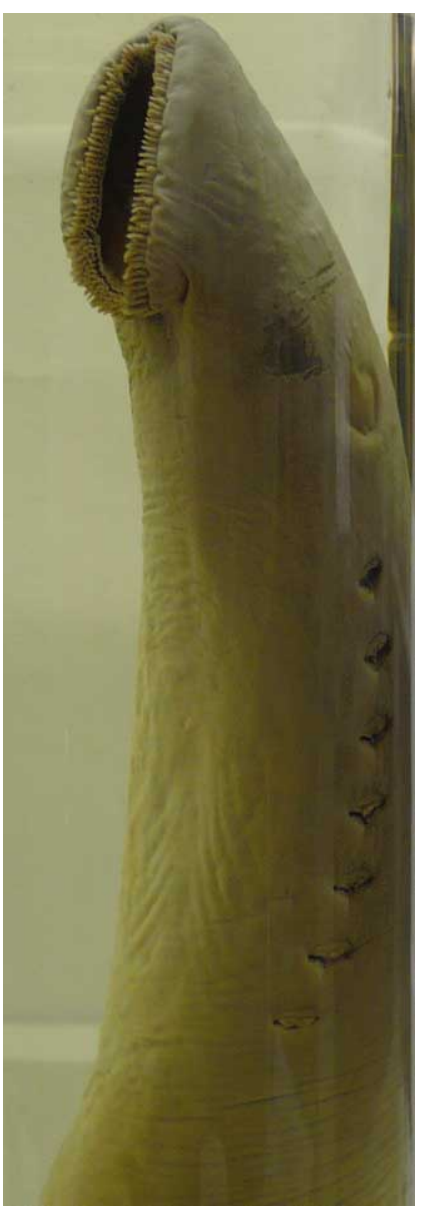

Fig. 3. Vertebrados agnatos. Vista lateral de la lamprea. Nótese la presencia de 7 arcos branquiales
Una clase específica de genes homeobox, denominados genes Hox, son expresados secuencialmente a lo largo del eje anteroposterior de la faringe embrionaria, estableciendo un patrón de expresión génica en el ectomesénquima denominado "código Hox". Los genes Hox de los amniotos están dispuestos en tandem en 4 clusters, cada uno de los cuales es encontrado en un cromosoma diferente (McGinnis \& Krumlauf, 1992). Así cada uno de los arcos faríngeos lleva un subconjunto de Hox transcritos que determinan diferentes vías de desarrollo, entregando posiciones claves en la ocupación del ectomesénquima en cada arco faríngeo. Es importante notar que no hay expresión de genes Hox en el primer arco (mandibular).
Así, parte del programa de desarrollo de la mandíbula parece ser regulado por un estado por defecto "libre de Hox" y ha sido visto en una serie de experimentos, en donde se observa que si se induce la expresión de Hoxa-2 (un gen del arco Hioideo) en el primer arco, se llega al desarrollo de elementos del $2^{\circ}$ arco y viceversa (Kuratani, 2004). También se ha visto que el transplante de células ectomesenquimáticas libres de la expresión de Hox a nivel del segundo arco, generan una duplicación de los elementos esqueléticos de la mandíbula en un sector que debiera desarrollar un arco hioideo (Noden, 1983; Couly et al., 1998). El factor de crecimiento fibroblástico-8 (FGF8) liberado desde el romboencéfalo embrionario posibilita la inhibición en la expresión de genes Hox en las células de cresta neural correspondientes (Trainor et al., 2002).

En consecuencia, la mandíbula de los vertebrados es considerada aparentemente como una "innovación evo- 

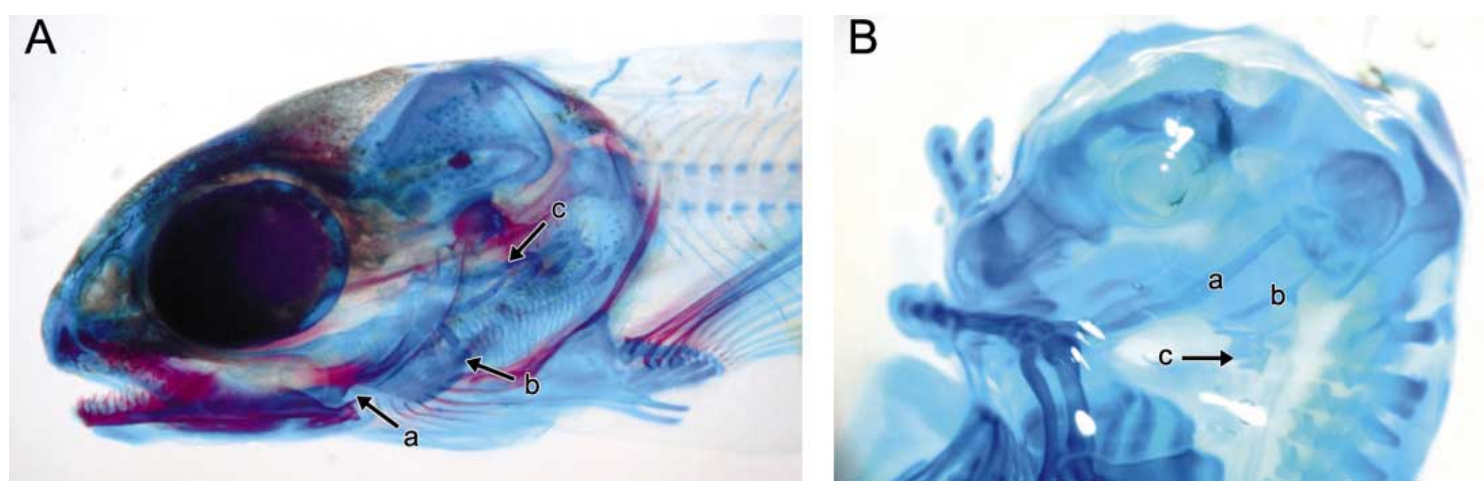

Fig. 4. Evolución de los elementos cartilaginosos de los arcos branquiales desde teleósteos a mamíferos. (A) Alevín de salmón. (B) Embrión ovino. a) Cartílago del primer arco; b) Cartílago del Segundo arco; c) Elementos derivados de tercer, cuarto y quinto arcos. Técnica de Wassersug para cartílago y hueso.

lutiva" en una definición de Wagner \& Müller (2002), que ha sido posible por un cambio heterotípico de la regulación de un gen.

La forma de fijación de la mandíbula al cráneo es muy importante al momento de investigar la evolución. El modo paleostílico, presente en los agnatos, representa el estado de fijación más primitivo, en el cual ninguno de los arcos se une directamente al cráneo. La condición mandibulada más antigua es la euautostílica que estuvo presente en los peces primitivos placodermos y acantodos, en la cual el arco mandibular se une al cráneo sin la ayuda del arco hioideo. La mayor parte de los tiburones actuales presenta una suspensión mandibular anfistílica, en donde el arco mandibular se une por 2 ligamentos al cráneo; uno anterior que se inserta en el palatocuadrado y otro posterior que se inserta en la hiomandíbula. En la mayor parte de los peces modernos la articulación es hiotílica, en donde el arco mandibular se une a la caja craneana a través de la hiomandíbula (Fig. 4). En la mayoría de los anfibios, reptiles y aves, la articulación mandibular es metautostílica, en donde la fijación mandibular es directa a la caja craneana mediante el hueso cuadrado, la hiomandíbula no interviene en el soporte mandibular, en cambio da origen a la columnilla o estapes, implicada en la audición. Y en conjunto con elementos del $3^{\circ}$ arco faríngeo se forma el
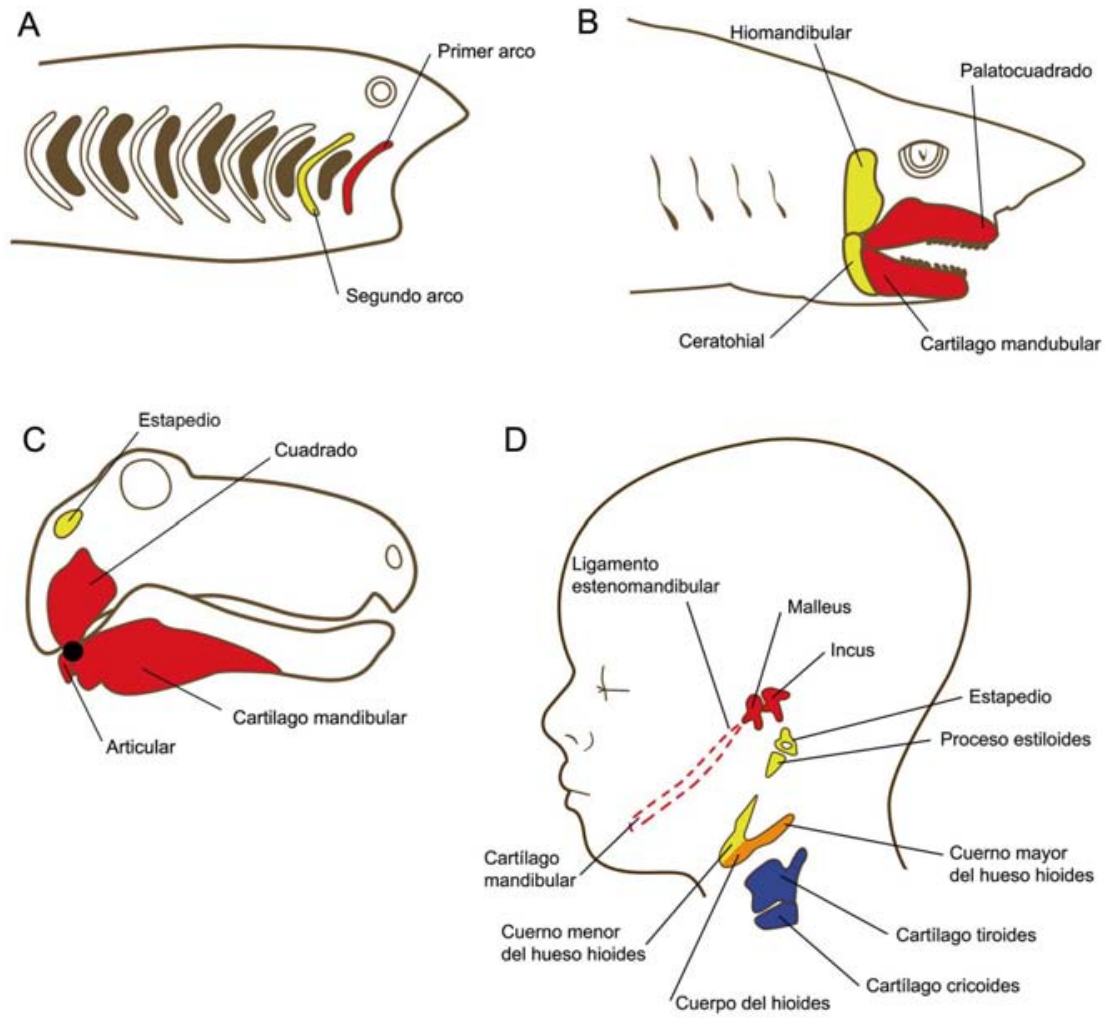

Fig. 5. Modelos evolutivos del esplacnocráneo. (A) Agnato, (B) Condrictio, (C) Reptil, (D) Mamífero. Se visualiza como los elementos del primer arco (color rojo) forman la mandíbula con la consecuente incorporación de los elementos posteriores al oído medio. En amarillo se visualizan elementos derivados del $2^{\circ}$ arco faríngeo.

apararato hioideo que sostiene la lengua y el piso de la cavidad oral. En los mamíferos la suspensión mandibular es craniostílica (Fig. 4). En este tipo de articulación toda la mandíbula superior se incorpora a la caja craneana y la mandíbula inferior queda suspendida del hueso escamoso del cráneo. La mandíbula inferior queda así formada únicamente por hueso dentario, el cual es de origen dérmico y envuelve al cartílago del primer arco. Los cartílagos palatocuadrado y del primer arco se osifican en sus extremos posteriores y respectivamente dan lugar al incus y al malleus del oído medio (Kardong, 2007). En la figura 5 se puede observar la evolución del esplacnocráneo. 
Los arcos faríngeos (Fig. 6) emergen en una dirección cráneo - caudal durante la ontogenia (Grevellec \& Tucker, 2010). El primer arco faríngeo se observa al día 17 de gestación en porcinos; al día 18 en ovinos (Orzag, 1985) y en equinos (Acker et al., 2001), y en el humano a partir del día 24 son evidenciables.

Cada arco faríngeo presenta un cartílago (el cual aportará el componente esquelético de la región de la cara y el cuello), una rama arterial proveniente del saco aórtico denominada arco aórtico, y un nervio que inervará los derivados de cada arco. Externamente entre los arcos, se forman cuatro surcos o hendiduras faríngeas (Fig. 6). Al mismo tiempo, se originan evaginaciones de las paredes laterales de la faringe, constituyendo las bolsas faríngeas (Fig. 6).

Formación de la cara. El desarrollo de la cara es similar en todos los mamíferos. En conjunto con la región mandibular ocurre un fenómeno tridimensional que implica formación, crecimiento, fusión y moldeado de una gran variedad de tejidos. El prosencéfalo actúa como soporte mecánico y como centro emisor de señales para el desarrollo facial primitivo, mientras que el estomodeo funciona como punto morfológico de referencia. La región maxilar y mandibular de la cara derivan del primer arco faríngeo, que en parte del mesénquima facial proviene de células de la cresta neural.

A finales del período somítico, el estomodeo queda limitado en su parte craneal por una prominencia frontonasal única, dos nasales mediales y 2 nasales laterales, caudalmente por los prominencias mandibulares y a ambos lados por las prominencias maxilares (Fig. 7). El maxilar contiene una población mixta de células
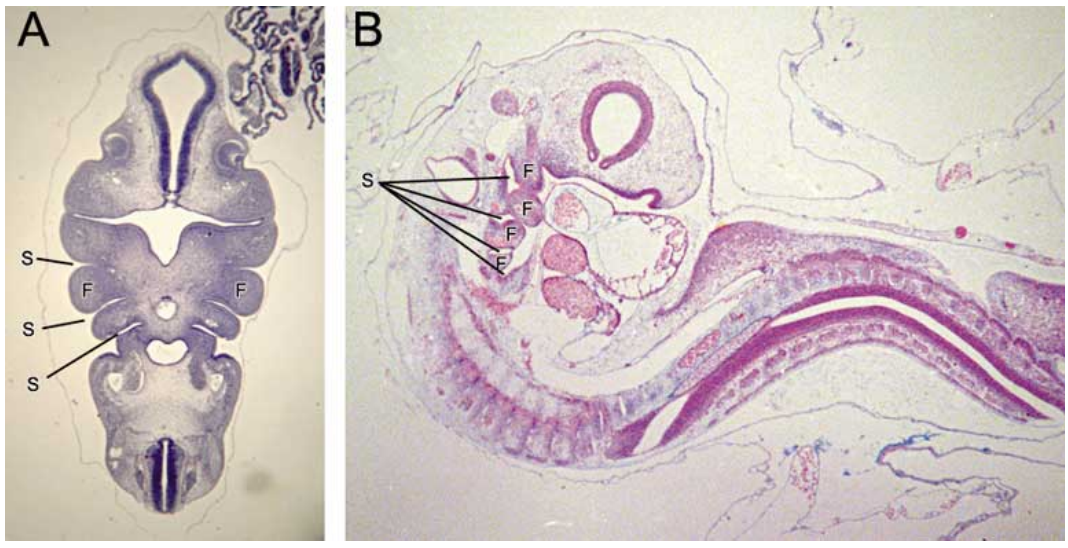

Fig. 6. (A) corte frontal de embrión de cerdo en período somítico. (B) corte sagital de embrión de pollo de 72 hrs. de gestación. Aumento 30X. (F) Arcos faríngeos, (S) hendiduras faríngeas
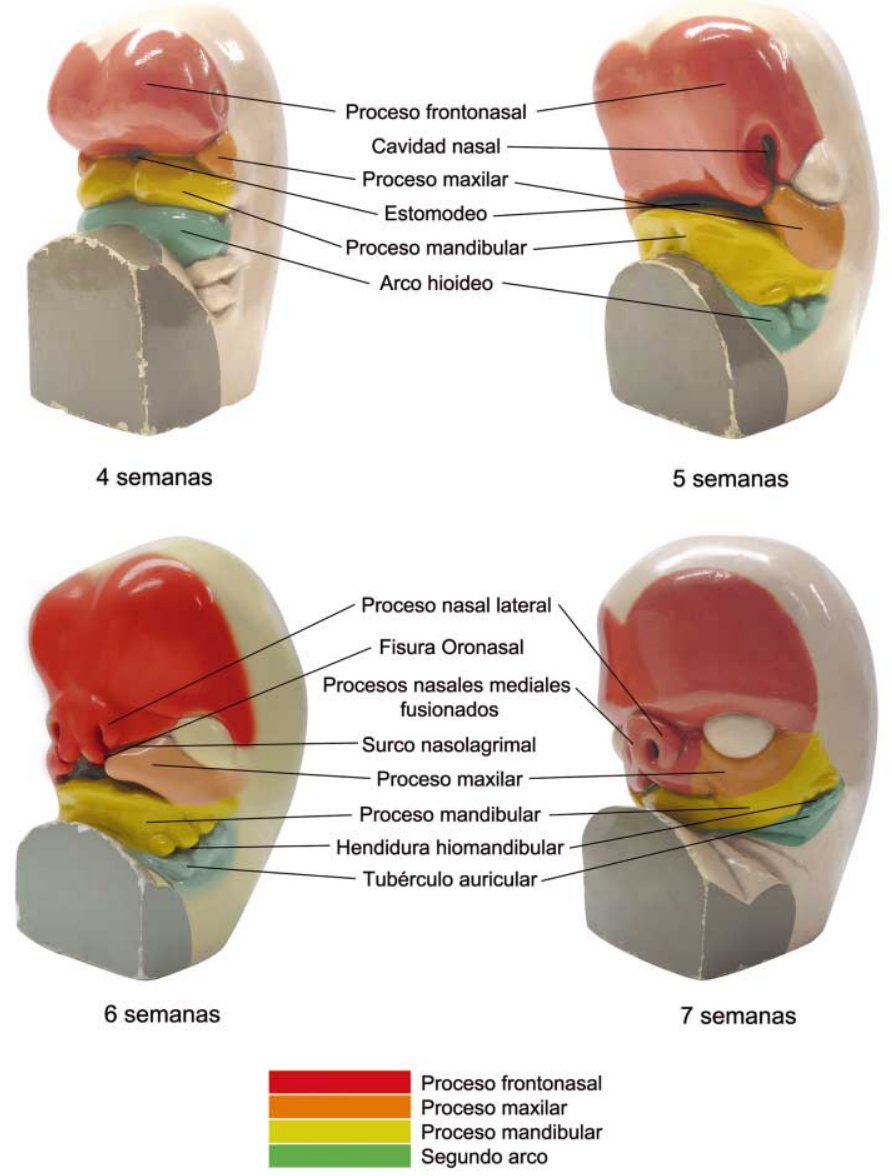

Fig. 7. Vistas frontales y laterales de modelos de cara humana entre 4 y 7 semanas de gestación. Cada prominencia queda representada por un color. El rojo corresponde a la prominencia frontonasal, el naranjo a la prominencia maxilar, el amarillo representa el proceso mandibular, y el verde al segundo arco faríngeo. de la cresta neural, derivadas del prosencéfalo y del mesencéfalo, mientras que la mandíbula contiene células mesenquimatosas procedentes de la cresta neural del mesencéfalo y del romboencéfalo (rombómeros 1 y 2).

El proceso frontonasal es una estructura destacada en las primeras fases del desarrollo facial, y su formación resulta de un sistema de señales muy sensible, que comienza con la síntesis de ácido retinoico en una región del ectodermo localizada frente al mesencéfalo (Osumi-Yamashita, 1996). El ácido retinoico, posiblemente a través de la mediación de la población más rostral de células de la cresta neural, man- 
tiene las señales de FGF-8 y de Sonic hedgehog tanto en el prosencéfalo anterior como en el ectodermo frontonasal que lo cubre (Helms et al., 1997). Estas dos moléculas transductoras de señales estimulan la proliferación celular en el mesénquima de la cresta neural del proceso frontonasal. La ausencia de estas señales produce un aumento de la muerte celular en dicha región, así como una disminución de la proliferación celular, lo que da a lugar a diversos defectos mediofaciales. Tanto el déficit como el exceso de ácido retinoico pueden producir defectos muy similares.

Durante la quinta semana de gestación en humanos aparecen los esbozos de las cavidades nasales, a partir de la invaginación de dos engrosamientos localizados en el ectoderma de la zona inferior del proceso frontonasal, las placodas olfatorias. Estos engrosamientos se forman por inducción del prosencéfalo, y la aparición de las cavidades olfatorias divide el proceso frontonasal en un proceso nasal medio, y un proceso nasal lateral. Engrosamientos semejantes, ubicados lateralmente en el proceso frontonasal, dan origen a las placodas del lente (cristalino).

Las cavidades olfatorias se profundizan y el epitelio de la placoda, que se ubica en su techo, se diferencia formando el neuro-epitelio olfatorio. Cuando el resto de la membrana se rompe, se forman las coanas primitivas, comunicando las cavidades nasales con la cavidad oral. Con el crecimiento de los procesos maxilares y nasales, el proceso frontonasal se aleja de la región oral.

Los procesos maxilares y mandibulares derivan del primer arco faringeo. Su crecimiento se inicia por señales procedentes del ectodermo apical de estos procesos, estimulando el crecimiento del mesénquima de los primordios faciales. Este mesénquima presenta una importante expresión del gen Msx-1 durante el crecimiento (Alappat et al., 2003). Los precursores del primer arco faríngeo se caracterizan por expresar el factor de transcripción Otx-2 en vez de los genes Hox que no se expresan a este nivel.
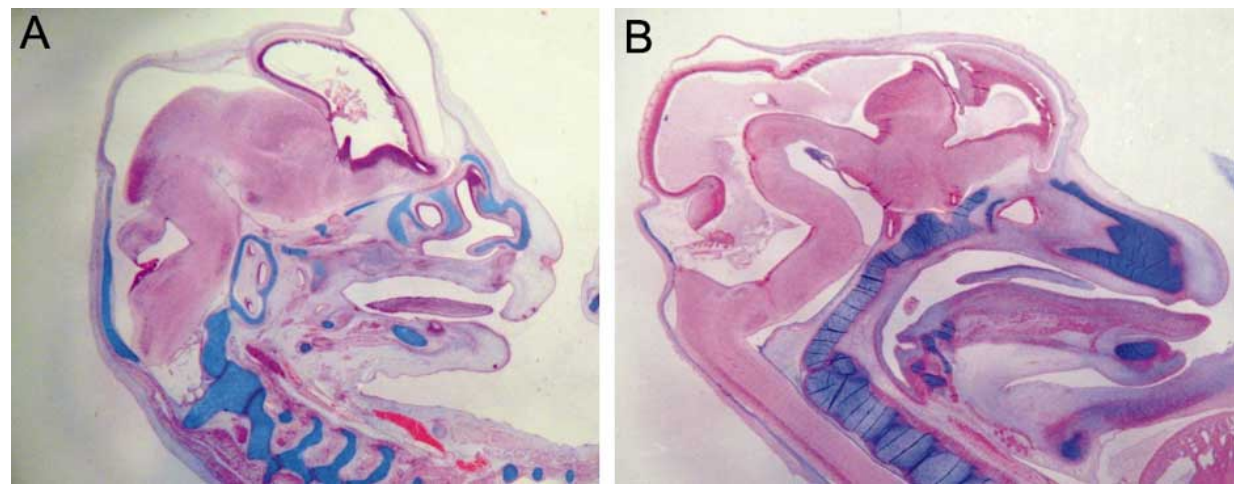

Fig. 8. Esqueleto facial de gato (A) muestra su arquitectura braquicéfalica, en comparación con el ovino (B), cuya arquitectura es dolicocéfalica. Técnica H-E azul de Alcian 8X.
El desarrollo de la mandíbula se inicia en dos centros de osificación membranosa en el mesénquima del proceso mandibular, durante la $7^{\mathrm{a}}$ semana de desarrollo. Comienza en la vecindad del ángulo formado por los ramos de los nervios mental y alveolar inferior, al separarse del nervio mandibular. $\mathrm{Al}$ inicio se forma un semianillo óseo alrededor del nervio y arteria y las trabéculas óseas se extienden hacia atrás y delante. De este modo el hueso del cuerpo mandibular en desarrollo, tiene el aspecto de un canal abierto hacia arriba donde se alojan el paquete neurovascular y los gérmenes dentales. Al avanzar la osificación el cartílago mandibular involuciona, excepto en su parte distal donde origina 2 huesos del oído medio y en su extremo medial donde experimenta osificación endocondral.

El mecanismo de osificación membranosa involucra la acción de los factores de crecimiento BMP-2, 4 y 7 que actúan desde la epidermis de la región, activando en células derivadas de la cresta neural, un factor de transcripción, el Cbfa-1, el cual transforma las células mesenquimáticas en osteoblastos. Del mismo modo, la sobreexpresión de BMP cambia el patrón esqueletal resultando alterado el tamaño y morfología de la cara (Montenegro \& Rojas, 2007).

Existen alteraciones del desarrollo que afectan específicamente a regiones mediales o laterales de la mandíbula, lo que hace pensar que influyen diferentes factores. La región medial del proceso mandibular responde a señales epiteliales locales de FGF-2 y FGF-4, estimulando el mesénquima subyacente a través de Msx-1; por otro lado, la región lateral depende de señales de FGF-8. Las moléculas BMP-4 y BMP-7 producidas en la región lateral del proceso mandibular regulan el mecanismo apoptótico de la zona (Carlson, 2005).

Respecto a la formación mandibular en mamíferos se ha visto que la formación del hueso mandibular en gatos (Felis catus) es retardada en comparación con el ovino (Ovis aries). Este fenómeno se inicia en gatos a los 32 días (53\% de gestación), mientras que en ovejas comienza entre los días 31- 32 (21\% de gestación). Otra diferencia entre ambas especies es la conformación del cartílago del primer arco, y su participación en la osificación de la mandíbula, generando la arquitectura anatómica característica de los gatos (braquicefálicos) y de los ovinos (dolicocéfalos) (Fig. 8) (Rojas \& Montenegro, 1996). 
Los procesos nasomediales y maxilares terminan fusionándose y dando lugar al labio superior y maxilar (Fig. 7D; Fig. 9). Los procesos nasomediales forman el segmento intermaxilar, el cual dará lugar al philtrum del labio superior, el componente premaxilar del maxilar (donde se ubican los 4 incisivos), la porción mediana de la nariz y el paladar primario (el cual adopta una forma triangular). Los procesos nasolaterales formarán las alas de la nariz.

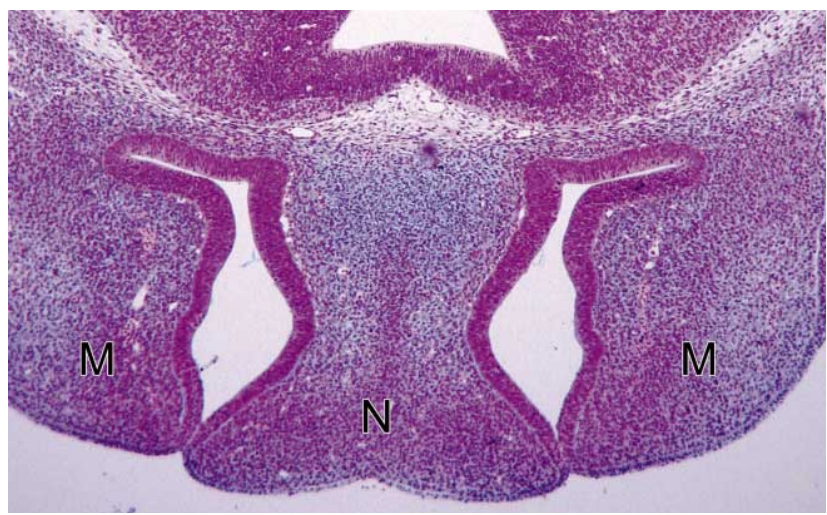

Fig. 9. Procesos nasomediales (N) y maxilares (M) en embrión de ratón de 11 días post fecundación. Técnica H-E-azul de Alcián, $50 \mathrm{X}$.

Las profundas fisuras faciales que existen entre los procesos se cierran totalmente. La fisura oronasal, ubicada entre el proceso maxilar y el nasomediano, se fusiona completamente, la fisura óculonasal, ubicada entre el proceso maxilar y el nasolateral, se cierra superficialmente por sus caras externa e interna, dejando en el interior un cordón epitelial macizo, el que posteriormente se canaliza originando el canal y conducto nasolagrimal y cerca de la órbita al saco lagrimal. El conducto nasolacrimal se extiende desde la comisura medial del párpado inferior hasta la cavidad nasal (meato inferior) y en la vida posnatal actúa como sistema de drenaje de las lágrimas. La persistencia completa de esta fisura se denomina coloboma facial.

El proceso de fusión es una de las etapas críticas del desarrollo facial. En las líneas de fusión se forma una lámina epitelial y luego mediante dos mecanismos; apoptosis y transformación epiteliomesenquimática el epitelio involuciona y se consolida la fusión del mesénquima (Fig. $10)$.

A medida que avanza el desarrollo, la cara se ensancha transversalmente, acercándose las órbitas gradualmente hacia el plano mediano.

Los procesos mandibulares fusionados tempranamente por debajo del estomodeo, además de participar en la formación ósea de la mandíbula, originan el labio inferior,

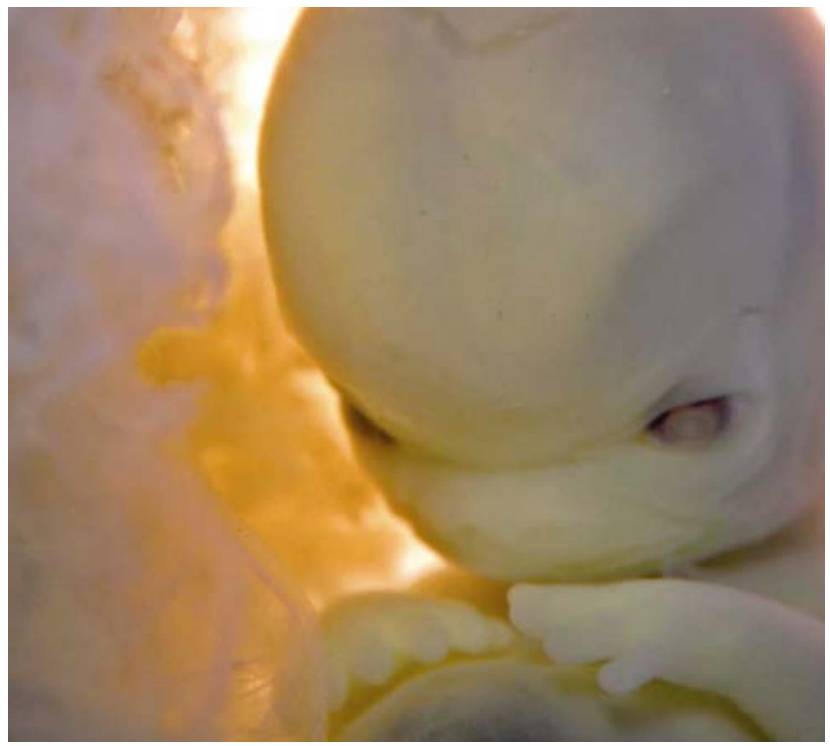

Fig. 10. Cara de embrión humano de 7 semanas de gestación. Nótese los procesos faciales fusionados, y las órbitas de ubicación lateral.

el mentón y la mitad inferior de las mejillas. Por su parte, los procesos maxilares forman la mitad superior de las mejillas y las regiones laterales del labio superior.

Músculos de la región facial. El tejido mesenquimático, de origen mesodérmico, formará los músculos estriados de la cara. Este tejido migra tempranamente desde el primer arco faríngeo, en el caso de los músculos masticadores, siendo inervado por el nervio trigémino ( $\mathrm{V}$ nervio craneal); y desde el segundo arco, formando los músculos faciales los cuales serán inervados por el nervio facial (VII nervio craneal) (Fig. 11).

Formación del paladar y la lengua. En humanos, durante la $6^{\circ}$ semana (en ratones a los 12 días) de gestación existe una cavidad oral y nasales comunes, ocupada principalmente por la lengua muy desarrollada. A ambos lados de la lengua se encuentran los procesos palatinos laterales, los cuales emergen desde la cara interna de los procesos maxilares, inicialmente crecen en sentido vertical y luego se horizontalizan y constituyen el paladar secundario ( $7^{\circ} \mathrm{se}-$ mana en humanos, 14 días en el ratón). En sentido ventral se forma el proceso palatino medio como una invaginación de los procesos nasomediales. En la medida que este proceso crece se transforma en una estructura triangular, denominada paladar primario, en cual posteriormente pasará denominarse componente premaxilar que contiene los 4 dientes incisivos superiores.

Así, el paladar deriva de los tres primordios mencionados: un proceso palatino medio y dos procesos palatinos 
A

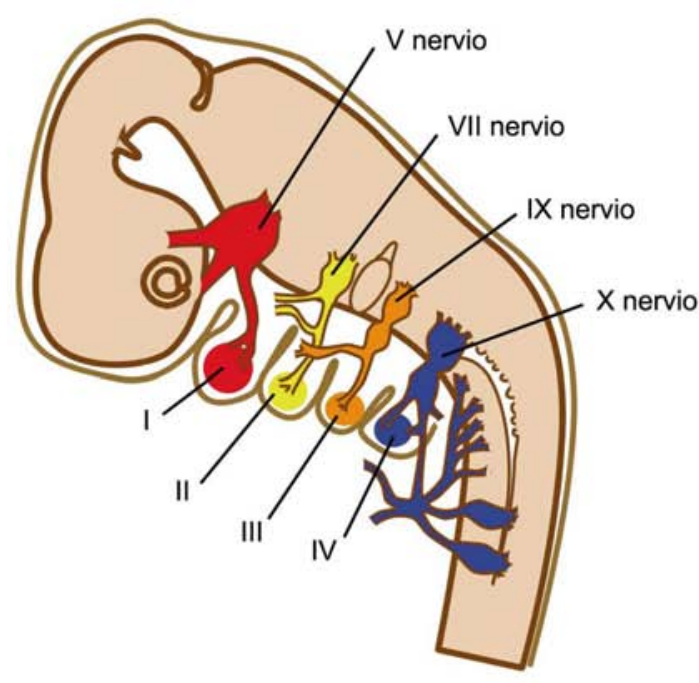

B

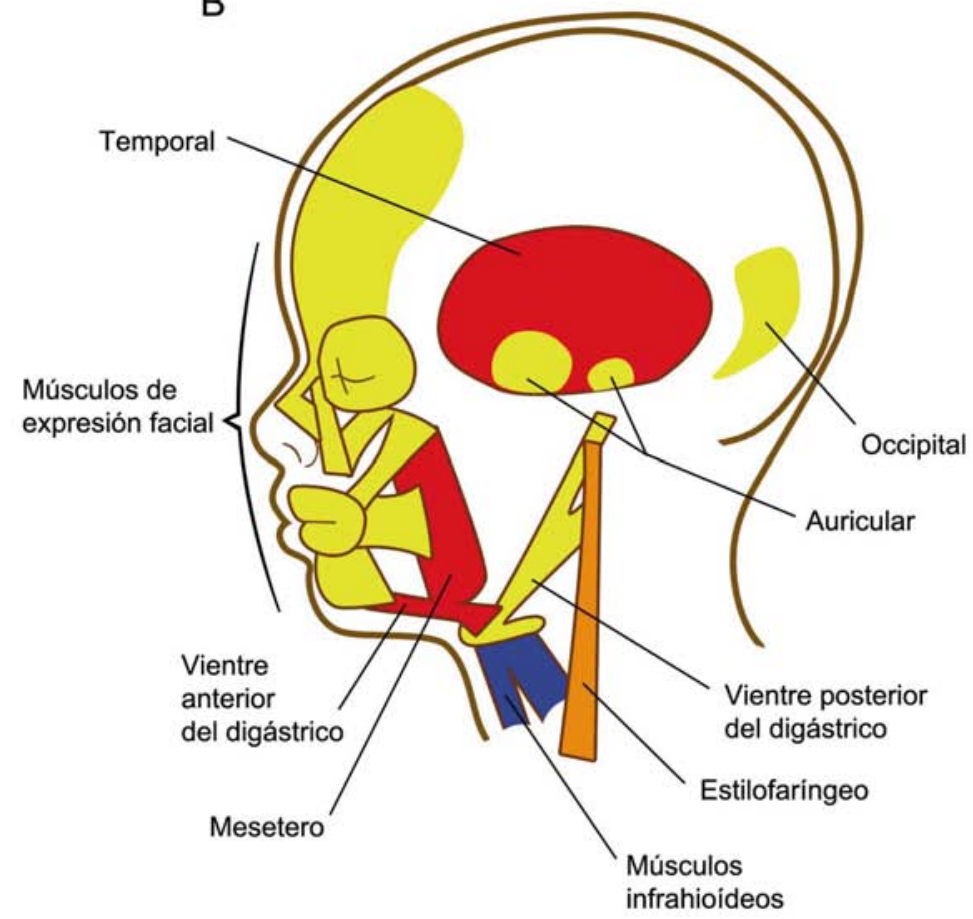

Fig. 11. Formación de los músculos faciales y su respectiva innervación dependiente del arco faríngeo de origen (modificado de Carlson, 2005).

laterales. En su formación intervienen el crecimiento de estos procesos, elevación, fusión y eliminación del rafe epitelial en el sitio de fusión (Fig. 12).

Al igual que en el caso de los primordios faciales, en el crecimiento de los procesos palatinos participan interacciones mesénquimo-ectodérmicas, así como factores de crecimiento específicos. La acción de Msx-1 en el mesénquima del proceso palatino estimula una cascada de señales conducidas por BMP-4, que a su vez induce las señales de Shh en el ectodermo apical. La expresión de Shh induce señales de BMP-2 en el mesénquima subyacente, así la combinación de BMP-2 y BMP-4 estimulan la proliferación del mesénquima y el crecimiento del proceso palatino.
Cuando se forma el cuello embrionario, se produce un descenso de la lengua y otros órganos ubicados en posición alta. En este momento, los procesos palatinos experimentan un cambio de posición, es decir se horizontalizan. Este es un movimiento rápido, brusco y constituye otra fase crítica del desarrollo.

Los mecanismos que subyacen a la elevación de los procesos palatinos no se conocen por completo. Algunas investigaciones, realizadas en animales de laboratorio, indican que este cambio de posición se debe al aumento de ácido hialurónico en la matriz extracelular de los procesos palatinos. El porcentaje de ácido hialurónico es alto inicialmente y disminuye después de la reorientación. Por su habi-
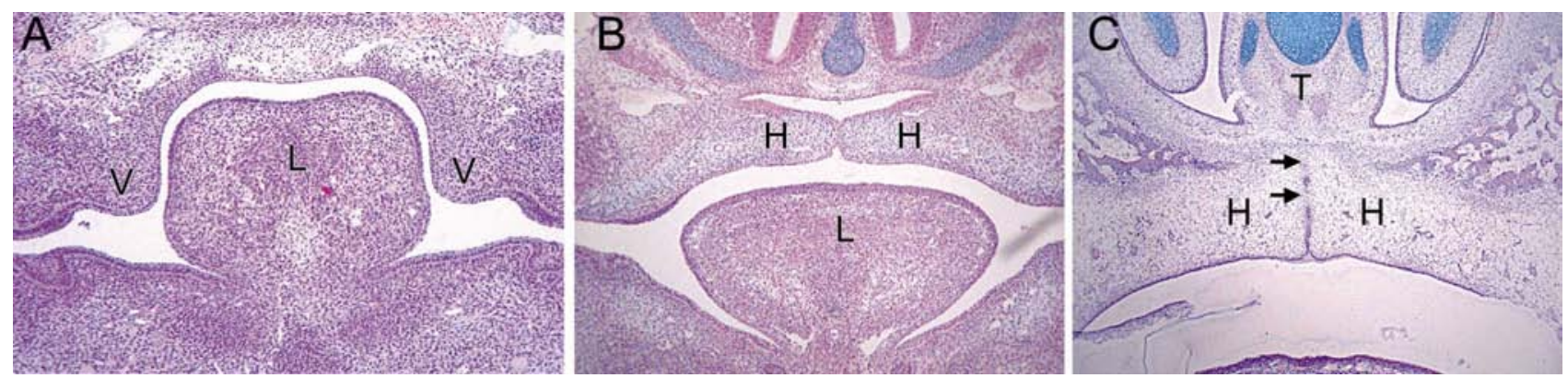

Fig. 12. Palatogénesis. Procesos palatinos verticales (V) a ambos lados de la lengua (L). B. Procesos palatinos horizontales (H) C. Procesos palatinos fusionados entre sí y con el tabique (T), nótese la presencia de la fusión mesenquimática luego de la apoptosis (Flechas). 
lidad de unirse al agua, esta molécula se expande generando una fuerza intrínseca dentro del proceso, que permite la elevación. Esta fuerza elevadora del proceso es ayudada por manojos de colágeno tipo I, cuya síntesis también aumenta durante este período (Montenegro \& Rojas, 2005).

Durante el período de la elevación, casi no hay crecimiento en el ancho de la cabeza, pero sí un constante crecimiento en altura de la cabeza. Además, los músculos de la lengua se hacen funcionales en este período. Los embriones humanos empiezan a hipar, pero aún no hay apertura de la cavidad oral, ni deglución, ni succión, lo cual ocurre después del cierre del paladar (Palomino \& Montenegro, 2002).

El tabique nasal es otra de las estructuras que participan en la formación del paladar. Esta estructura de la línea mediana, que es el resultado del crecimiento inferior de la prominencia frontonasal, alcanza el nivel de los procesos palatinos una vez que éstos se han fusionado para formar el paladar secundario definitivo. En dirección rostral, el tabique nasal se continúa con el paladar primario. De este modo los procesos palatinos que se fusionan entre si en la línea mediana, también fusionan rostralmente con el paladar primario. El punto de fusión en la línea mediana del paladar primario con los dos procesos palatinos es el foramen incisivo.

A medida que el paladar y la cabeza crecen en altura, la lámina epitelial mediana (rafe epitelial medio) se adelgaza a una sola capa de células y se rompe en pequeños islotes. Simultáneamente la lámina basal desaparece y las células epiteliales extienden filopodios hasta el mesénquima subyacente, se amplían los espacios entre ellas y adoptan la morfología de fibroblasto, dejan de expresar citoqueratinas y empiezan a expresar vimentina. De este modo migran hacia el tejido conectivo, permitiendo la continuidad del tejido mesenquimático (Montenegro \& Rojas, 2001). Esto ocurre en el día 15 de gestación en ratón y durante la $9^{\circ}$ semana en humanos.

En la desaparición del rafe epitelial de la línea media, tras la aproximación de los procesos palatinos, se ven implicados varios procesos fundamentales del desarrollo. Algunas de las células epiteliales del rafe de fusión experimentan apoptosis y desaparecen. Otras células pueden migrar desde el plano de fusión y formar parte del revestimiento epitelial de la cavidad oral. Otro grupo de células epiteliales puede sufrir una transformación morfológica y convertirse en células mesenquimales por medio de la acción del factor de crecimiento transformante-b3 (TGF-b3). Este último se expresa en las células ectodérmicas del borde distal de los procesos palatinos, justo antes de su fusión y pierden importancia después (Richman et al., 1997). En ratones que sufren mutaciones de TGF-b3, los procesos palatinos laterales se acercan a la línea mediana, pero el rafe epitelial no desaparece, desarrollando una fisura de paladar aislada (Taya et al., 1999).

El cierre del paladar secundario se inicia en la región mediana y desde allí se extiende hacia el paladar primario, y luego hacia la región posterior de la úvula. Con la formación del paladar secundario, la comunicación de las fosas nasales con la cavidad oral se desplaza hacia atrás, estableciéndose las coanas definitivas.

El paladar definitivo queda formado por el paladar primario, derivado de los procesos nasales medios, y por el paladar secundario, derivado de los procesos palatinos. La línea de fusión queda demarcada en el adulto por una línea en forma de $\mathrm{Y}$, cuyo vértice corresponde al agujero incisivo.(palatino anterior).

Desarrollo comparado del paladar. En aves, los procesos palatinos bilaterales emergen desde los procesos maxilares, pero en vez de crecer verticalemente, como en mamíferos, crecen horizontalmente sobre el dorso de la lengua. Los procesos palatinos se aproximan y contactan, pero sus epitelios no adhieren, ni se fusionan, ni se produce muerte celular, sino que se queratinizan, manteniendo una fisura. Algunos reptiles como lagartijas tienen un desarrollo similar al de las aves y una fisura palatina natural (Ferguson et al., 1994).

Otro grupo de reptiles como cocodrilos sin embargo, tienen un paladar secundario fusionado, similar al de los mamíferos. En estos animales, los procesos palatinos bilaterales emergen desde los procesos maxilares, y en los $4 / 5$ anteriores del paladar crecen horizontalmente sobre el dorso de la lengua. Mientras que en el quinto posterior del paladar, crecen verticalmente, se remodelan a una posición horizontal y la fusión ocurre similar a los mamíferos.

Anfibios y otros reptiles como algunas especies de tortugas y culebras, sólo tienen un paladar primario algo más desarrollado, originado de los procesos nasales medios, formando el techo de la cavidad oral. El desarrollo del paladar secundario está ausente en vertebrados inferiores, incluyendo peces. Por lo tanto, filogenéticamente la fisura palatina es ancestral al paladar fusionado.

Se ha estudiado el desarrollo del paladar secundario en bovinos (Bos taurus) y la secuencia de su formación la podemos ver resumida en la tabla 2 (Rojas et al., 1984).

En todos los vertebrados, el epitelio nasal se diferencia en un epitelio cilíndrico, pseudoestratificado ciliado y el epitelio oral en uno escamoso estratificado. 
Desarrollo de la lengua. En embriones de 5 semanas, la lengua está representada por un par de engrosamientos linguales laterales, presentes en las regiones ventrales de los primeros arcos faríngeos y por 2 engrosamientos mediales impares, los cuales son: el tubérculo impar localizado entre el primer y segundo arco y la cópula (yugo) localizada entre el segundo y tercer arco. El foramen ciego que indica el emplazamiento original del primordio tiroideo, sirve de punto de referencia útil para delinear el límite entre el tubérculo impar original y la cópula. En situación caudal respecto a la cópula se encuentra otro engrosamiento del cuarto arco que representa la epiglotis.

Los 2/3 anteriores de la lengua están revestidos por ectoderma, mientras que el endoderma cubre su tercio posterior.

A medida que avanza el desarrollo, las protuberancias linguales laterales aumentan mucho de tamaño, fusionándose entre sí y con el tubérculo impar, originando el cuerpo de la lengua (Fig. 13). La raíz de la lengua deriva de la cópula y del tejido ventromedial adicional existente entre el tercer y cuarto arcos branquiales.

La musculatura de la lengua proviene desde los miotomos occipitales y es invervada por el nervio hipogloso (XII). La inervación sensitiva general de los diferentes sectores de la lengua, se explica por el origen de sus componentes. Así, el epitelio del cuerpo lingual, derivado del primer arco faríngeo, es inervado por un ramo del trigémino (V par); la inervación de la porción vertical de la raíz lingual derivada de los III y IV arcos faríngeos, es inervada respectivamente por los nervios glosofaríngeo y vago (IX y X pares).
Las papilas de la lengua inician su desarrollo durante la séptima semana de gestación en humanos; aparecen como engrosamientos de la mucosa en las regiones correspondientes, dando origen a las papilas filiformes y gustativas. Las papilas filiformes constituyen la gran mayoría, su desarrollo es muy similar al de los folículos pilosos, es decir, el ectodermo genera señales inductivas (Shh, BMP-2, BMP-4 y FGF-8) sobre un núcleo de mesénquima. Las papilas gustativas aparecen en base a un dispositivo intrínseco de señales dentro del epitelio lingual de origen endodérmico, mediado por un mecanismo en el que participan Shh, Gli-1 y patched. La mantención de las papilas gustativas una vez formadas se hace muy dependiente de su inervación, la cual proviene de los nervios VII y IX.

Formación de los dientes. Un diente consiste en una matriz extracelular muy especializada, en cuya composición participan dos elementos principales denominados esmalte y dentina, cada uno de ellos secretados por un epitelio embrionario diferente. El desarrollo comienza con la migración de células de la cresta neural hacia los maxilares y la mandíbula. Durante la sexta semana de gestación en humanos, prolifera el epitelio ectodérmico que reviste los procesos maxilares y mandibulares, introduciéndose en el mesénquima subyacente y formando dos estructuras que adoptan la forma de herradura denominadas láminas dentales. Dependiendo de la especie puede existir participación de tejido endodérmico (Bei, 2009).

A medida que la lámina dental crece en el mesénquima se forman una serie de proliferaciones en forma de yema que constituyen los brotes o gérmenes dentarios (esbozos de las piezas dentarias temporales). Así en humanos, se forman 10

A

B

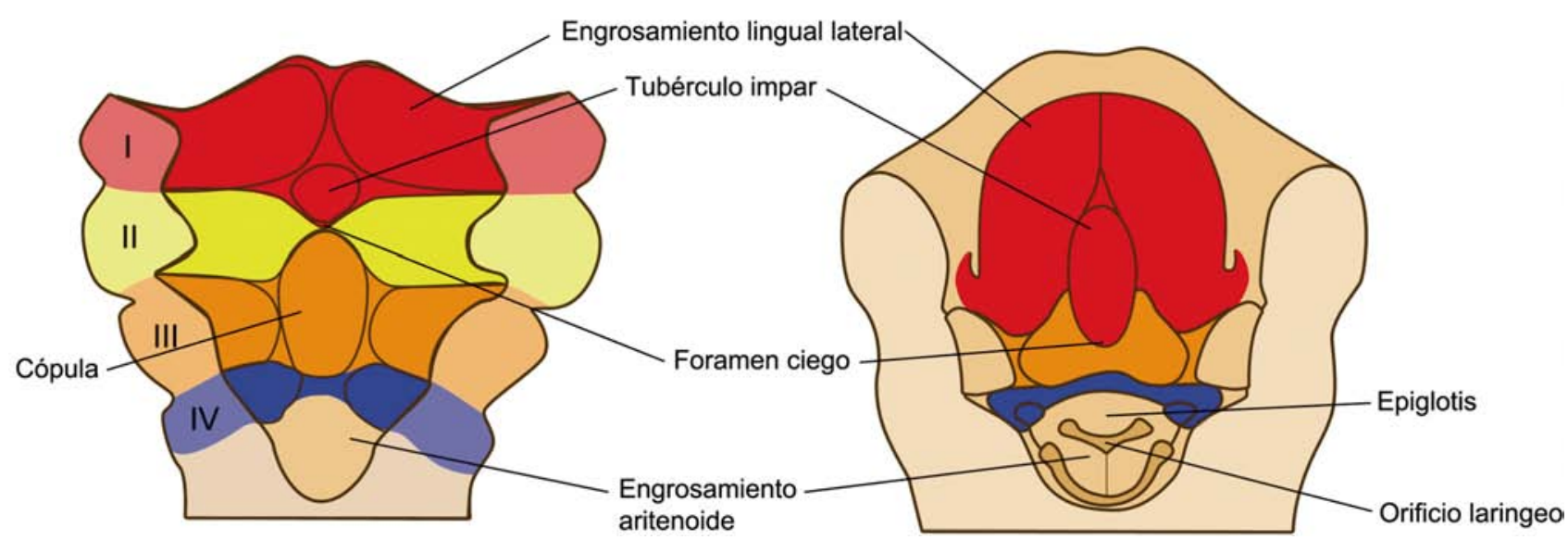

Fig. 13. Vista ventral de los arcos faríngeos, que ilustran el desarrollo de la lengua. (A) Cinco semanas de gestación (B)Tres meses de gestación en humanos (modificado de Carlson, 2005). 
brotes en los maxilares y 10 en la mandíbula. Cada uno de estos brotes epiteliales se asocia con tejido mesenquimático que se condensa, provocando la invaginación del esbozo epitelial, el cual adopta la forma de una copa o casquete, hasta llegar al estado de campana (Fig. 14).

Cuando se encuentra en el estado de campana, el componente epitelial se denomina órgano del esmalte y se encuentra conectado aún al epitelio oral por un pedículo irregular de lámina dental en degeneración. El órgano del esmalte se compone de tres capas: una vaina epitelial externa, un retículo estrellado de tipo mesenquimatoso y una capa epitelial interna de ameloblastos. Los ameloblastos son las
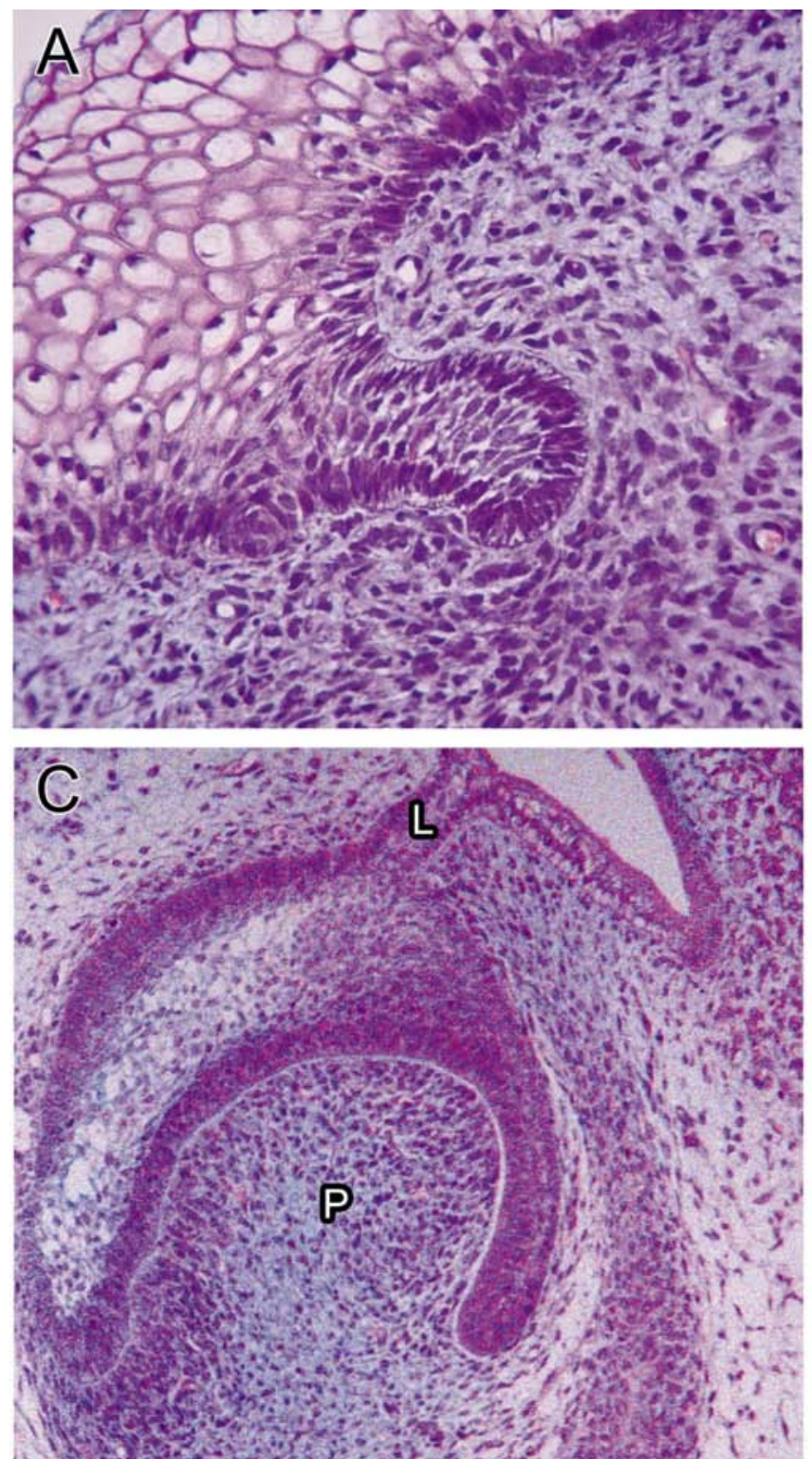

células que secretan el esmalte dental. En la concavidad del órgano del esmalte se ubica la papila dental, la cual es una condensación de mesénquima de la cresta neural. A partir de células de la papila se diferenciarán los odontoblastos que formarán la dentina y el resto constituirá la pulpa dentaria (Fig. 15).

En las etapas tardías del estado de campana, los odontoblastos y ameloblastos comienzan a secretar los precursores de la dentina y el esmalte. La forma definitiva del diente se adquiere a lo largo de varios meses. Alrededor del diente en desarrollo se forma una condensación de células mesenquimatosas que se denomina saco dental, el cual dará
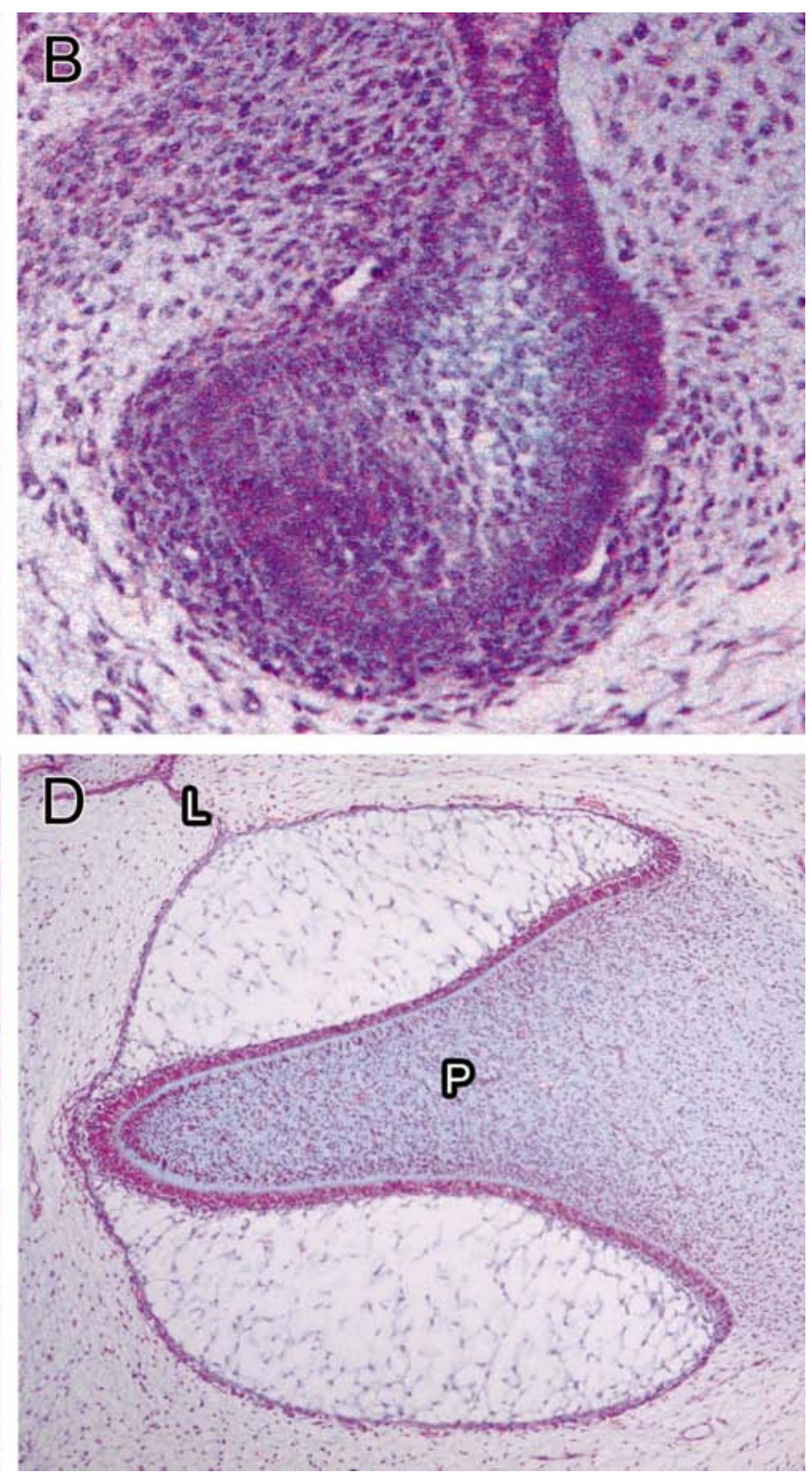

Fig. 14. Germen dental. (A) Etapa de yema inicial, (B) Etapa de yema más avanzada, (C) Etapa de Copa, (D) Etapa de campana. Lamina (L), Papila (P). 


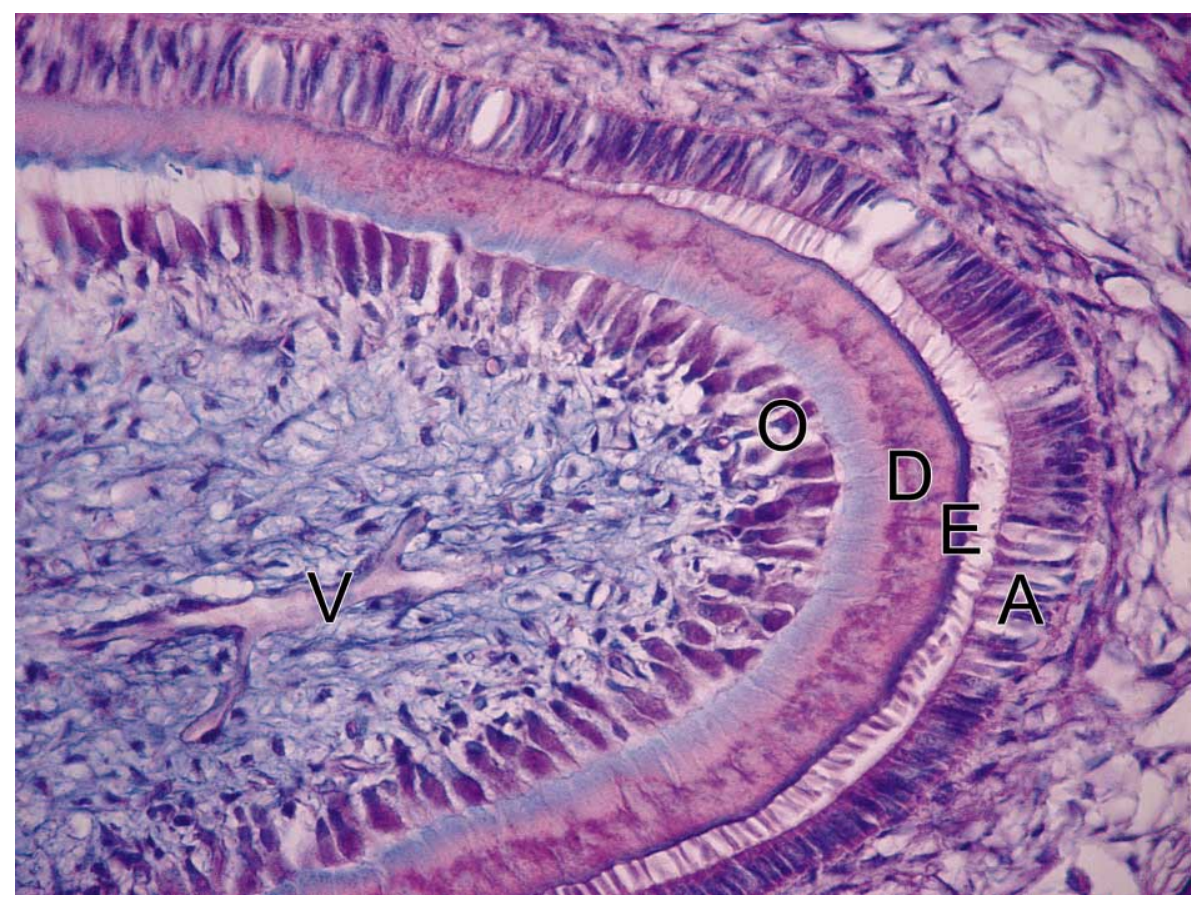

Fig. 15. Configuración celular del órgano del esmalte y pulpa dental. (V) Vaso sanguíneo de la pulpa, (O) Odontoblasto, (D) Dentina, (E) Esmalte, (A) Ameloblasto

origen al cemento y al ligamento periodontal. Estos componentes especializados facilitan la unión firme entre el diente y los huesos maxilares o mandibulares.

Los estudios en humanos y animales han permitido identificar un número importante de genes que participan en las diferentes etapas del desarrollo dental y que regulan tanto el patrón de formación como la diferenciación. Muchos de estos estudios demuestran que la formación de los dientes es el resultado de un estricto control de las redes de genes y moléculas activadoras e inhibidoras, y que cualquier modificación de estas redes conduce a alteraciones en cualquiera de los números o los patrones.

Las vías de señalización de BMP, FGF, SHH y Wnt constituyen las claves que se utilizan reiteradamente durante el desarrollo dental, mediando en las interacciones epitelio-mesenquimales.

La expresión inicial de FGF-8 en el ectodermo estimularía la expresión de Pax-9 por parte del mesénquima subyacente. La falta de expresión de Pax-9 se traduce en que el desarrollo del diente no pasa de la etapa de yema. El ectodermo también produce BMP-2 y BMP-4, que inhiben la acción FGF8, esto explicaría los espacios interdentarios. Msx-1 es otro factor de trascripción característico inducido por el mesénquima que se encuentra subyacente a la lámina dental engrosada, mutaciones en MSX-1 causan agenesia dental selectiva en humanos y en ratas la mutación homocigota resulta en una falla completa del desarrollo dental. Se cree que hay un mecanismo en el cual Bmp-4 depende de la expresión de Msx-1 (Alappat et al.).

La inactivación de FGF8 en el epitelio dental resulta en una detención del desarrollo en estado de lámina. La sobreexpresión de BMPR1 (receptor de BMP), o la inactivación funcional de FGFR2b o SHH resulta en una detención del desarrollo dental en etapa de yema.
La pérdida de Ectodin lleva al crecimiento de dientes supernumerarios a través de la inhibición de la señal de BMP. La soobreexpresión de Ectodysplasin (Eda), un mediador de la señal Wnt, genera dientes supernumerarios. Del mismo modo la sobreexpresión de b-catenina resulta en dientes supernumerarios (Bei).

A pesar del progreso en el conocimiento del desarrollo dental, el proceso involucrado en la formación de dientes extras o en el reemplazo dental aún es desconocido. Algunos estudios sugieren que Pitx2 y Bmp4 son las claves asociadas con el reemplazo continuo de dientes en peces (Fraser et al., 2006). Los esfuerzos actuales se centran en encontrar la vía para regenerar dientes y utilizar esta vía con el objeto de llevar células troncales hacia la diferenciación dental.

Actualmente se han encontrado células troncales mesenquimales (MSCs) tanto en la pulpa dental como en el folículo dental. Estas células han sido cultivadas in vitro obteniendo colonias de odontoblastos, cementoblastos y células de ligamento periodontal (Yao et al., 2008). Aún no existe evidencia de que estas células sean capaces de iniciar la morfogénesis dental directamente.

\section{Formación del cuello. Deriva- dos de las bolsas faríngeas y tiroides. En mamíferos, la re- gión del cuello se caracteriza por la presencia de cuatro arcos con hendiduras en el lado externo (sitio ectodérmico) y bolsas en el lado interno (sitio en- dodérmico) (Fig. 16).}


A

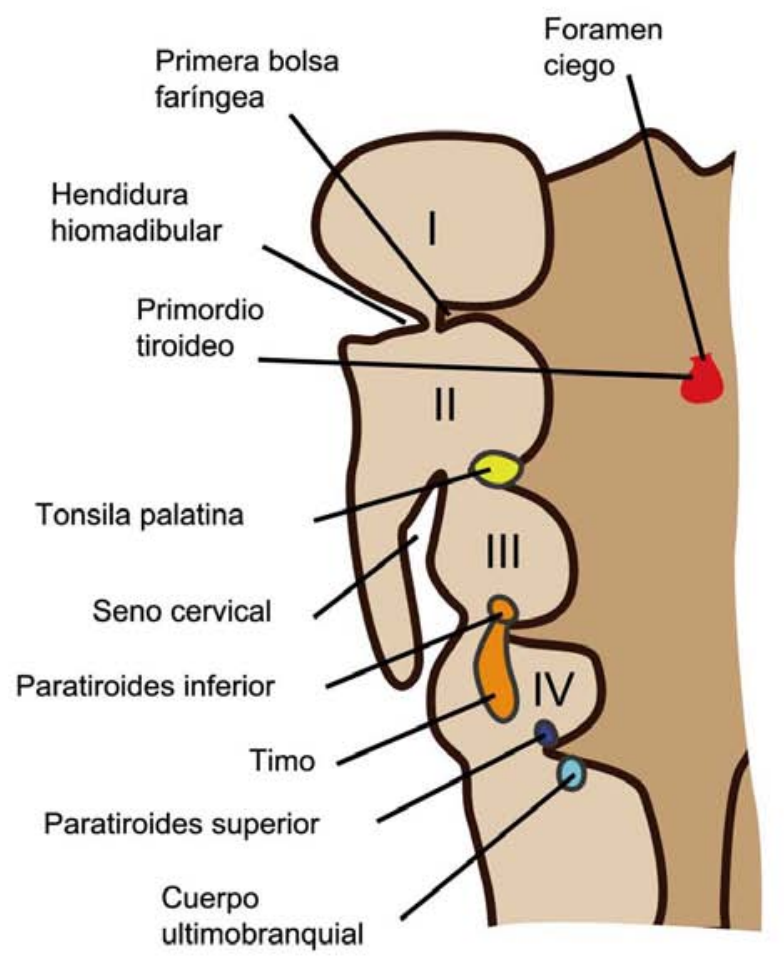

B

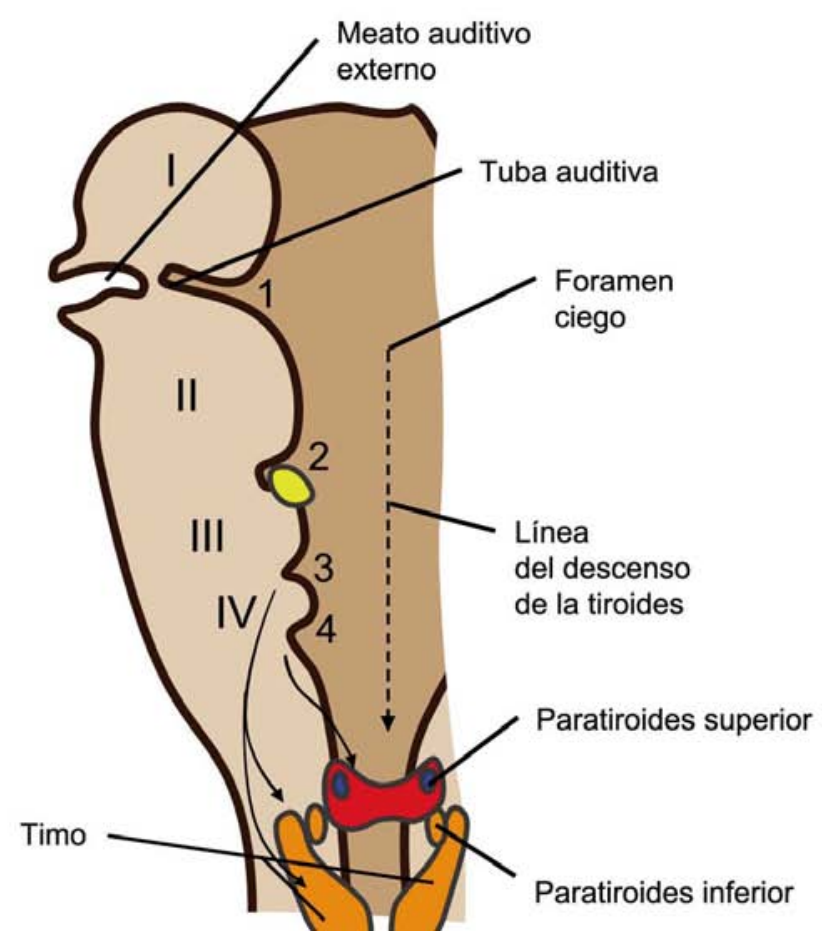

Fig. 16. Arcos faríngeos, formación del cuello y derivados de las bolsas faríngeas (modificado de Carlson, 2005).

Hemos mencionado la relevancia de los genes Hox en la identidad morfológica de cada arco. Adicional al patrón Hox, existen señales moleculares procedentes del ectodermo y del endodermo a la hora de determinar las características anteroposteriores de los arcos, y los genes Dlx controlan el desarrollo a lo largo del eje proximodistal. La formación del primer arco faríngeo es independiente del ácido retinoico, no así la del tercer y cuarto, los que en ausencia de ácido retinoico no se desarrollan de manera correcta, presentando alteraciones en el patrón de expresión endodérmica para Hoxa-1, Hoxb 1, Pax-1, Pax-9, Fgf3 y Fgf-8 (Wending et al., 2000).

La primera hendidura faríngea es la única que persiste como estructura reconocible en el adulto dando lugar al meato auditivo externo. Las hendiduras II y III se ven cubiertos por el aumento de tamaño de la porción externa del segundo arco, en homología a lo que ocurre con el opérculo de los peces. El crecimiento del segundo arco se debe a la presencia de un centro de señales en el extremo del ectodermo que no se encuentra en el tercer o en el cuarto arco. Este centro de señales produce Shh, FGF-8 y BMP-7 que estimulan el crecimiento del mesénquima subyacente. El espacio que queda entre el segundo arco que ha crecido y las hendiduras II y III se denomina seno cervical. A medida que avanza el desarrollo, el segundo arco en crecimiento se fusiona con el ectodermo de la eminencia cardíaca, con lo cual el seno cervical desaparece y cuello toma un aspecto liso.

Las bolsas faríngeas son evaginaciones endodérmicas, ubicadas a ambos lados de la faringe, entre los arcos faríngeos. Las cuatro primeras bolsas faríngeas están bien definidas, en cambio la quinta es atípica y se considera parte de la cuarta. Las bolsas faríngeas están revestidas por un epitelio derivado del endoderma faríngeo, del cual se originan importantes estructuras.

$\mathrm{Al}$ igual que ocurre con sus correspondientes primeras hendiduras faríngeas, las primeras bolsas participan en gran medida en la formación del oído dando origen a un divertículo, el receso tubo-timpánico, cuyo extremo distal se dilata formando la cavidad del oído medio o caja del tímpano. La porción proximal permanece estrecha y se convierte en la tuba auditiva (trompa de Eustaquio), que comunica la cavidad timpánica con la nasofaringe. La caja del tímpano se vincula con la vesícula auditiva, esbozo del oído interno. En su evolución posterior incluye la envoltura de los huesecillos del oído medio que tienen origen en el primer (incus y malleus) y segundo (estapedio) arcos faríngeos. El revestimiento endodérmico de la caja del tímpano contacta 
con el revestimiento epitelial ectodérmico de la primera hendidura branquial, quedando interpuesto entre ellos una delgada lámina de tejido mesenquimático. Estas tres capas representan el esbozo de la membrana del tímpano.

Las segundas bolsas faríngeas se vuelven menos profundas y menos visibles a medida que progresa el desarrollo del embrión. El endoderma que reviste las segundas bolsas faríngeas prolifera, formando yemas que se introducen en el mesénquima subyacente, dando origen a las tonsilas palatinas en las cuales se adosa tejido linfoide dentro de sus paredes en etapas más avanzadas del período fetal. El endodermo forma las criptas y tapiza la superficie amigdalina relacionada con la cavidad de la faringe. En el lado opuesto, el mesénquima aporta el armazón reticular y genera la cápsula del órgano.

Las terceras bolsas faríngeas se expanden dando origen a una porción dorsal sólida y una parte ventral elongada. Su conexión con la faringe se reduce a un conducto angosto que pronto degenera. Alrededor de la sexta semana, el epitelio de la parte dorsal se empieza a diferenciar en glándulas paratiroides inferiores. El esbozo ventral dará origen a la porción epitelial del timo (Fig. 16a). Al continuar el desarrollo, los dos esbozos tímicos pierden su conexión con la tercera bolsa faríngea y migran caudalmente hasta alcanzar su sitio definitivo en el tórax, donde se fusionan entre sí. En su desplazamiento, el timo arrastra consigo a las paratiroides inferiores, las cuales posteriormente se separan del timo y se ubican en la parte posterior de la glándula tiroides.

El endoderma faríngeo del timo da origen a las células retículo-epiteliales y a los corpúsculos tímicos. La cápsula y las trabéculas conectivas del timo tienen origen en el mesénquima. Estudios experimentales en embriones de pollo y ratón, han demostrado que el tejido mesenquimático del timo proviene de las crestas neurales cefálicas que migran hacia los arcos faríngeos y en ausencia de éstas el timo no se desarrolla. Los protimocitos (futuros linfocitos T), provienen desde el tejido hematopoyético.

Las cuartas bolsas faríngeas forman las glándulas paratiroides superiores. El epitelio de las bolsas faríngeas tercera y cuarta, que forman los esbozos de las paratiroides, proliferan formando pequeños nódulos entre los cuales penetra el mesénquima vascularizado para formar el estroma de las glándulas. Posteriormente éstas se desconectan de la faringe y se fijan a la glándula tiroides. El cuerpo últimobranquial se encuentra en la porción más ventral de la cuarta bolsa. Las células de los cuerpos último-branquiales se desprenden del epitelio endodérmico de las bolsas y se incorporan al esbozo de la glándula tiroides, donde se con- vierten en las células $\mathrm{C}$ o células parafoliculares, secretoras de calcitonina.

Formación de la glándula tiroides. La diferenciación de la glándula tiroides comienza durante la cuarta semana de gestación, a partir de un divertículo del endoderma del piso de la faringe, ubicado entre el tubérculo impar y la cópula (entre la primera y segunda bolsa faríngea, Fig. 13). La extensión caudal del divertículo tiroideo continúa a lo largo del desarrollo faríngeo. En el curso de la migración el extremo del divertículo se expande, se torna macizo y bifurca dando lugar a los lobos tiroideos conectados por un istmo (Fig. 16b). En este período de migración la glándula sigue conectada a su lugar de origen por el conducto tirogloso. Durante la séptima semana la glándula alcanza su ubicación definitiva delante del segundo y tercer cartílago traqueal, y el conducto tirogloso regresa, persistiendo sólo su extremo proximal como una pequeña depresión en el vértice de la $\mathrm{V}$ lingual, el agujero ciego. En muchos humanos la porción distal persiste en forma definitiva como lobo piramidal de la tiroides.

Al principio, el esbozo tiroideo está constituido por una masa sólida de células endodérmicas, que posteriormente se resuelve en una trama de cordones epiteliales como efecto de la invasión del mesénquima vascularizado de su entorno cercano. En humanos durante la décima semana de gestación se forman los folículos tiroideos, comenzando a aparecer el coloide en su interior; unas pocas semanas después es posible detectar la síntesis de tiroglobulina no yodada.

Algunas malformaciones faciales en humanos. Fisura labial: Se produce por la falta de fusión de los procesos maxilares y nasales medios correspondientes, pudiendo estar asociada o no a fisura de paladar. Puede ser unilateral (Fig. 17) o bilateral (Fig. 18). Su frecuencia es variable, en Chile se estima 1 de cada 620 recién nacidos.

Fisura velo-palatina o paladar hendido: Se debe a la falta de fusión de los procesos que forman el paladar. Se puede encontrar entre el paladar primario y los procesos palatinos (Fig. 19), en forma uni o bilateral. Habitualmente se asocia a fisura labial.

Coloboma facial o fisura oblicua: Anomalía poco frecuente, producida por la falta de fusión de los procesos maxilares y nasales laterales correspondientes. Puede ser uni o bilateral y puede presentarse asociada o no a fisura labial.

Síndromes de $1^{\circ}$ y $2^{\circ}$ arco faríngeo o disostosis craneofacial: Se incluyen patologías que cursan con hipoplasia de maxilar y mandíbula (micrognatia) en conjunto con microtia, es decir elementos derivados del primer arco 


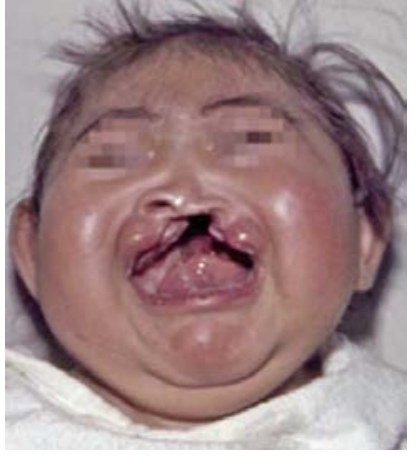

Fig. 17. Fisura labiopalatina unilateral.

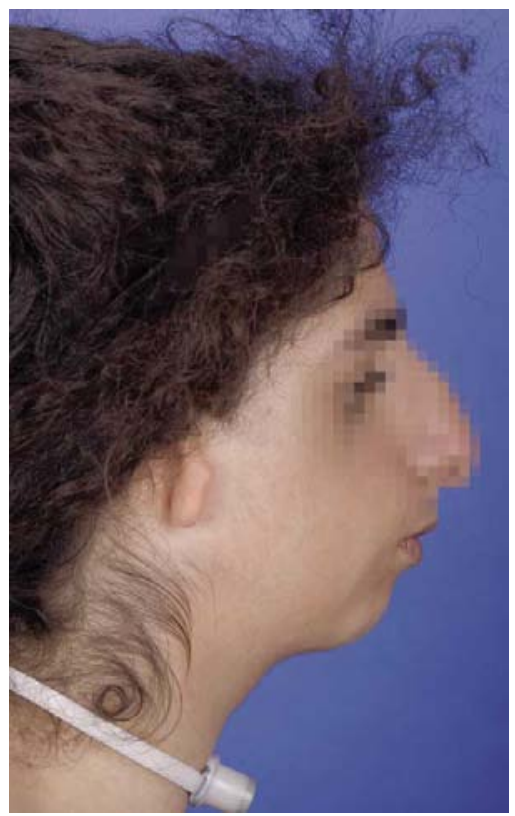

Fig. 20. Síndrome de Treacher Collins. Nótese la hipoplasia de maxilar y mandíbula.

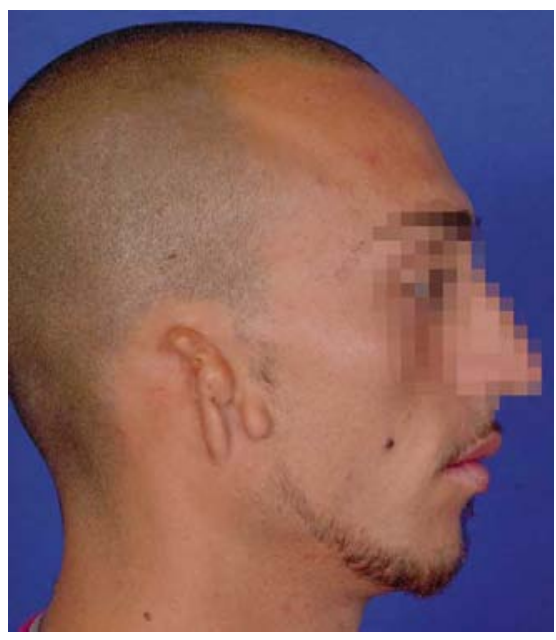

Fi. 22. Microtia.

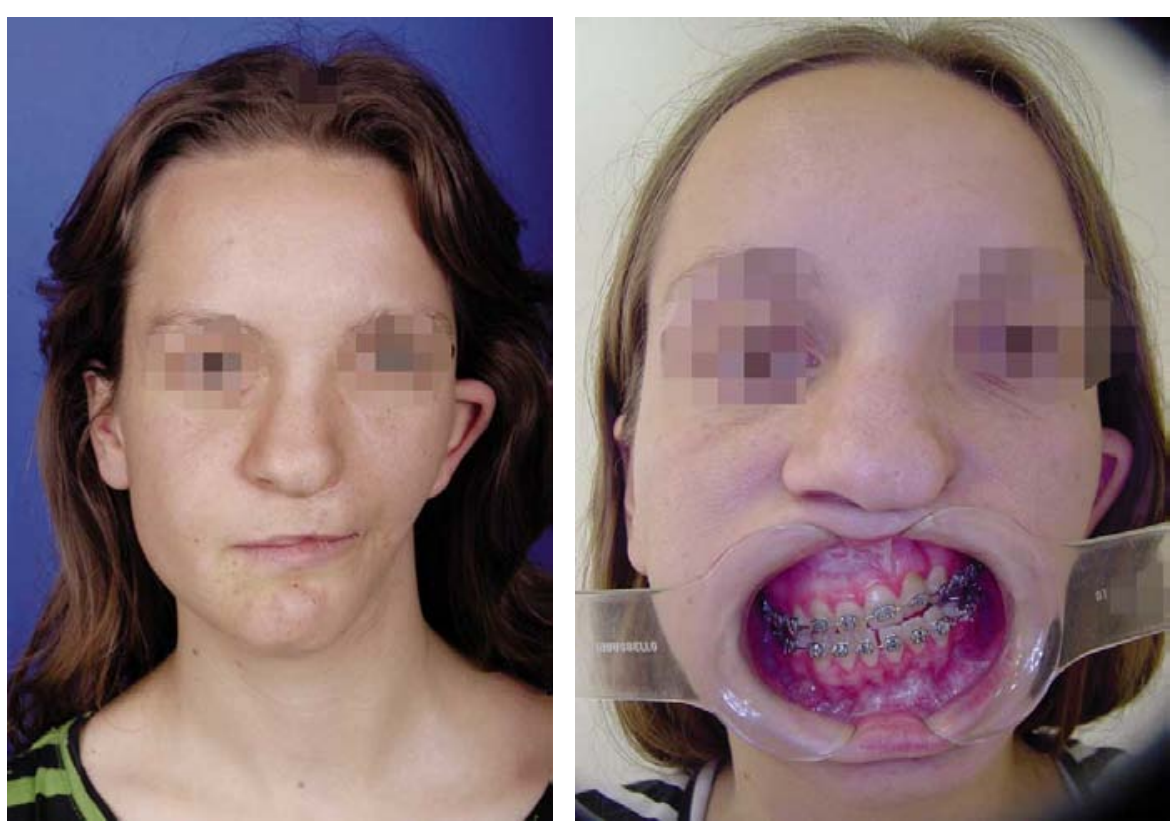

Fig. 19. Fisura de labio y paladar bilateral con ausencia del segmento medial (paladar primario).

Fig. 21. Microsomía hemifacial. Se aprecia un lado de la cara con hipoplasia y el otro normal.
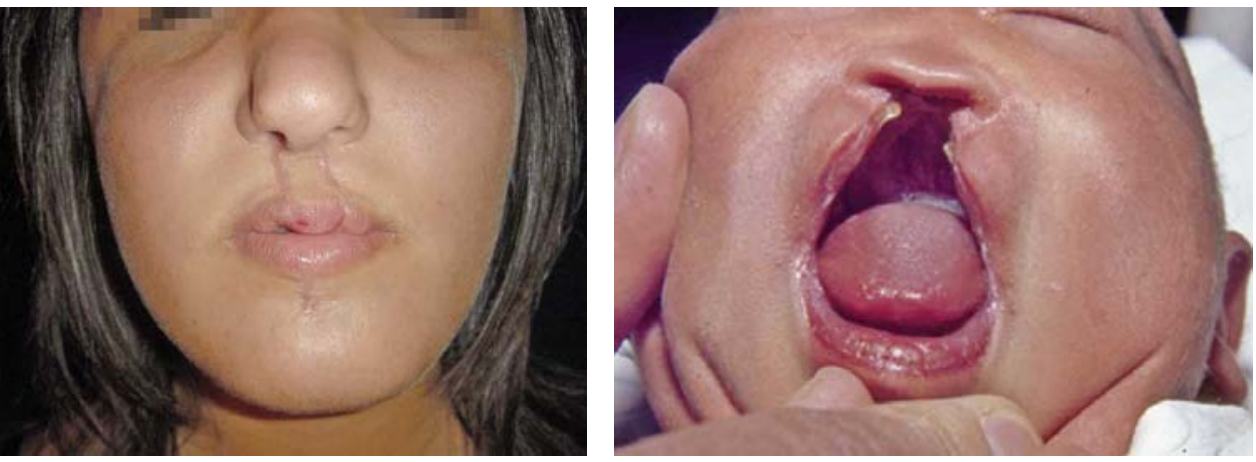

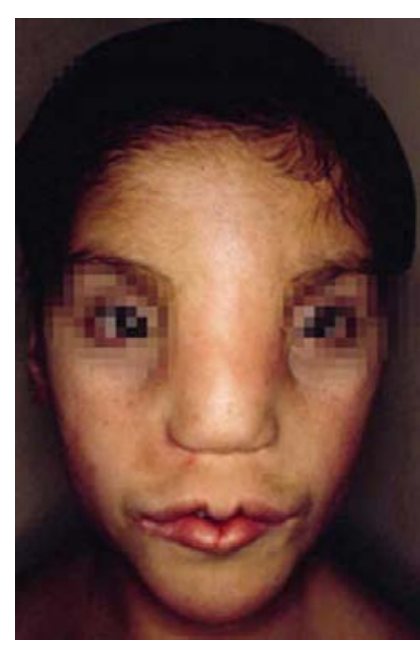

Fig. 23. Hipertelorismo.

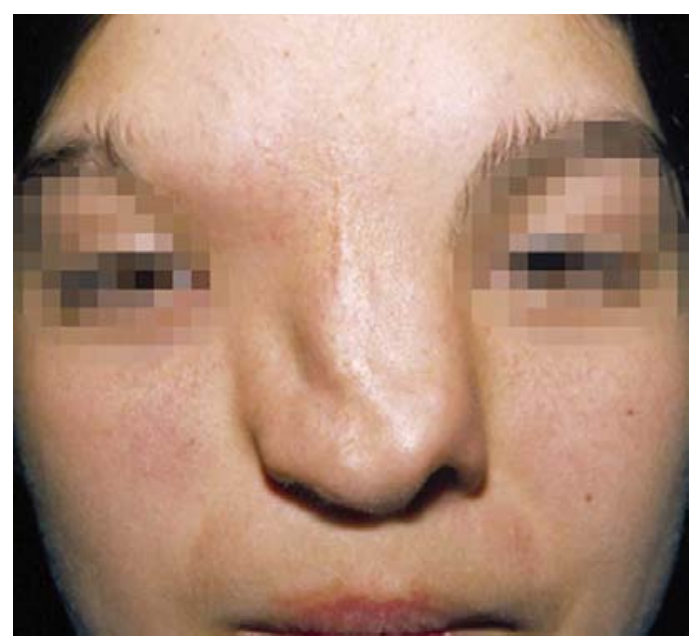

Fig. 24. Hipertelorismo con malformación nasal asociada. 
faríngeo. Clínicamente se representan por el síndrome de Treacher Collins (Fig. 20) y microsomía hemifacial (Fig. 21).

Microtía: Alteración del desarrollo del pabellón auricular, la cual pude ser aislada (Figura 22) o asociada a otro síndrome.

Teleorbitismo o Hipertelorismo: Separación excesiva de las órbitas, las causas pueden ser múltiples y puede estar asociado o no a otro síndrome (Fig. 23).

\section{AGRADECIMIENTOS}

Al Dr. Alberto Rodríguez T. por la revisión del manuscrito. El aporte de fotografías clínicas, fue gentileza del Dr. Roberto Hoppmann K. Las Ilustraciones y edición fotográfica fue realizada por el Sr. Simón Saavedra.

MERUANE, M.; SMOK, C. \& ROJAS, M. Face and neck development in vertebrates. Int. J. Morphol., 30(4):1373-1388, 2012.

SUMMARY: The embryonic development of the facial area, neck, nasal, oral and pharyngeal cavities with glands, involves growth and fusion of multi-dimensional processes. There is involvement of elements from the embryo-derived local 3 layers cells further neural crest derived cells from the neighbors rhombomeres. The neural crest cells are involved in the formation of local skeleton, among other structures. The study of evolution from jawless vertebrates shows us how Hox genes are expressed in different species, and how this determines the formation of different structures. The following review contemplate some morphological, molecular and evolutionary basis of facial and neck development, with emphasis on mammals with an epilogue concerning to the face and neck malformations in humans.

KEY WORDS: Face; Neck; Pharyngeal arches; Neural crest cells; Malformations.

\section{REFERENCIAS BIBLIOGRÁFICAS}

Acker, D.; Curran, S.; Bersu, E. \& Ginther, O. J. Morphologic stages of the equine embryo proper on days 17 to 40 after ovulation. Am. J. Vet. Res., 62(9):1358-64, 2001.

Alappat, S.; Zhang, Z. Y. \& Chen, Y. P. Msx homeobox gene family and craniofacial development. Cell Res., 13(6):429-42, 2003.

Bei, M. Molecular genetics of tooth development. Curr. Opin. Gen. Dev., 19:504-10, 2009.

Carlson, B. M. Embriología humana y biología del desarrollo. Elsevier. 2005. pp. 317-51.

Couly, G.; Grapin-Botton, A.; Coltey, P.; Ruhin, B. \& Le Douarin, N. M. Determination of the identity of the derivatives of the cephalic neural crest: incompatibily between Hox gene expression and lower jaw development. Development, 125:3445-59, 1998.

Ferguson, M. W. Craniofacial malformations: towars a molecular understanding. Nat. Genet., 6:329-30, 1994.

Fraser, G.J., Berkovitz, B.K. Graham, A., Smith, M.M. Gene deployment for tooth replacement in the rainbow trout (Oncorhynchus mykiss): a developmental model for evolution of the osteichthyan dentition. Evol. Dev., 8: 446-57, 2006.

Gilbert, S. Células de la cresta neural y especificidad axonal. Biología del desarrollo. $7^{\mathrm{a}}$ ed. Madrid, España Médica Panamericana, 2005. pp. 457- 96.
Grevellec, A. \& Tucker, A. S. The pharyngeal pouches and clefts: Development, evolution, structure and derivatives. Sem. Cell \& Dev. Biol., 21:325-32, 2010.

Helms, J. A.; Kim, C. H.; Hu, D.; Minkoff, R.; Thaller, C. \& Eichele, G. Sonic hedgehog participates in craniofacial morphogenesis and is down-regulated by teratogenic doses of retinoic acid. Dev. Biol., 187:25-35, 1997.

Kardong, K. V. Vertebrados. Anatomía comparada, función, evolución. McGrauw-Hill. Interamericana, 2007.

Kuratani, S. Evolution of the vertebrate jaw: comparative embryology and molecular developmental biology reveal the factors behind evolutionary novelty. J. Anat., 205:335-47, 2004.

McGinnis, W. \& Krumlauf, R. Homeobox genes and axial patterning. Cell, 68:283-302, 1992.

Montenegro, M. A. \& Rojas, M. Transformación epiteliomesenquimática durante el desarrollo embrionario. Rev. Chil. Anat., 19:301-10, 2001.

Montenegro, M. A. \& Rojas, M. Aspectos moleculares en la formación de la cara y del paladar. Int. J. Morphol., 23(2):18594, 2005.

Montenegro, M. A. \& Rojas, M. Factores que regulan la morfogénesis y el crecimiento mandibular humano. Int. J. Odontostomast., 1(1):7-15, 2007. 
Noden, D. M. The role of the neural crest in patterning of avian cranial skeletal, connective, and muscle tissues. Dev. Biol., 96:144-65, 1983.

Orszag, A. Características macroscópicas y microscópicas del desarrollo embriofetal del ovino (Ovis aries) entre los 18 y 96 días de gestación. Memoria título profesional Médico Veterinario. Facultad de Ciencias Veterinarias y Pecuarias. Universidad de Chile, Santiago, Chile, 1985.

Osumi-Yamashita, N. Retinoic acid and mammalian craniofacial morphogenesis. J. Biosci., 21:313-27, 1996.

Palomino, H. \& Montenegro, M. A. Genes y moléculas en el desarrollo cráneo-facial. Rev. Chil. Ortod., 19:20-31, 2002.

Richman, J.M.; Herbert, M.; Matovinovic, E. \& Walin, J. Effect of fibroblast growth factors on outgrowth of facial mesenchyme. Dev. Biol., 189:135-47, 1997.

Rojas, M.; Morales, B.; Estay, F. \& Montenegro, M. A. Light microscopic and histochemical study on the development of the bovine secondary palate (Bos taurus). Arch. Biol. (Bruxelles) 95:475-92, 1984.

Rojas, M. \& Montenegro, M. A. Embriogénesis del área mandibular e oveja (Ovis aries) y gato (Felis catus). Rev. Chil. Anat., 14(1):59-66, 1996.

Taya, Y.; O“Kane, S. \& Ferguson, M.W. J. Pathogenesis of the cleft palate in TGF-ß3 knockout mice. Development, 126:3869-79, 1999.

Trainor, P. A.; Ariza-McNaughton, L. \& Krumlauf, R. Role of the isthmus and FGFs in resolving the paradox of neural crest plasticity and prepatterning. Science, 295: 1288-91, 2002.

Wagner, G. P. \& Müller, G. B. Evolutionary innovations overcome ancestral constraints: a re-examination of character evolution in male sepsid flies (Diptera: Sepsidae). Evol. Dev., 4:1-6, 2002.

Wending, O.; Dennefeld, C.; Chambon, P. \& Mark, M. Retinoid signaling is essential for patterning the endoderm of the third and fourth pharingeal arches. Development, 127:1553-62, 2000 .

Yao, S.; Pan, F.; Prpic, V. \& Wise, G. Differentiation of stem cells in the dental follicle. J. Dent. Res., 87(8): 767-71, 2008.
Dirección para correspondencia:

Dr. Manuel Meruane N.

Av. Kennedy 7301 Dpto. D-104

Santiago

CHILE.

E-mail: mmeruane@vtr.net

Recibido : 02-03-2012

Aceptado: 06-05-2012 